\title{
Taphonomy of an excavated striped hyena (Hyaena hyaena) den in Arabia: implications for paleoecology and prehistory
}

\author{
Mathew Stewart ${ }^{1}$ (1) Eric Andrieux ${ }^{2,3} \cdot$ Richard Clark-Wilson $^{2} \cdot$ Nils Vanwezer $^{4} \cdot$ James Blinkhorn $^{2,4,5}$. \\ Simon J. Armitage ${ }^{2,6} \cdot$ Abdulaziz al Omari $^{7} \cdot$ Badr Zahrani $^{7} \cdot$ Mesfer Alqahtani $^{8,9} \cdot$ Mahmoud Al-Shanti $^{10}$. \\ lyad Zalmout ${ }^{11}$ - Yahya S. A. Al-Mufarreh ${ }^{11}$ - Abdullah M. Alsharekh ${ }^{12}$. Nicole Boivin ${ }^{4,13,14,15}$. \\ Michael D. Petraglia ${ }^{4,13,14,16}$. Huw S. Groucutt ${ }^{1,4,17}$
}

Received: 20 January 2021 / Accepted: 20 May 2021 / Published online: 20 July 2021

(c) The Author(s) 2021

\begin{abstract}
Studies of modern carnivore accumulations of bone (i.e., neo-taphonomy) are crucial for interpreting fossil accumulations in the archaeological and paleontological records. Yet, studies in arid regions have been limited in both number and detailed taphonomic data, prohibiting our understanding of carnivore bone-accumulating and -modifying behavior in dry regions. Here, we present a taphonomic analysis of an impressive carnivore-accumulated bone assemblage from the Umm Jirsan lava tube in the Harrat Khaybar region, Saudi Arabia. The size and composition of the bone accumulation, as well as the presence of hyena skeletal remains and coprolites, suggest that the assemblage was primarily accumulated by striped hyena (Hyaena hyaena). Our findings (1) identify potentially useful criteria for distinguishing between accumulations generated by different species of hyenas; (2) emphasize the need for neo-taphonomic studies for capturing the full variation in carnivore bone-accumulating and modifying behavior; (3) suggest that under the right settings, striped hyena accumulations can serve as good proxies for (paleo)ecology and livestock practices; and (4) highlight the potential for future research at Umm Jirsan, as well as at the numerous nearby lava tube systems. We encourage continued neo-taphonomic efforts in regions important in human prehistory, particularly in arid zones, which have received little research attention.
\end{abstract}

Keywords Carnivore $\cdot$ Bone accumulation $\cdot$ Livestock $\cdot$ Lava tube $\cdot$ Arabian Peninsula $\cdot$ Holocene

Mathew Stewart

mstewart@ice.mpg.de

1 Extreme Events Research Group, Max Planck Institutes for Chemical Ecology, The Science of Human History, and Biogeochemistry, Jena, Germany

2 Centre for Quaternary Research, Department of Geography, Royal Holloway, University of London, Egham TW20 0EX, Surrey, UK

3 Department of Archaeology, Durham University, South Road, Durham DH1 3LE, UK

4 Department of Archaeology, Max Planck Institute for the Science of Human History, Kahlaische Strasse 10 07743, Jena, Germany

5 Pan African Evolution Research Group, Max Planck Institute for the Science of Human History, Jena, Germany

6 SFF Centre for Early Sapiens Behavior (SapienCE), University of Bergen, Post Box 7805, 5020 Bergen, Norway

7 Ministry of Culture, Riyadh, Saudi Arabia

8 Department of Anthropology, University of Pittsburgh, Pittsburgh, PA, USA
9 Saudi Ministry of Culture, Ad Diriyah, Saudi Arabia

10 Department of Caves, Saudi Geological Survey, Riyadh, Saudi Arabia

11 Department of Paleontology, Directorate of Geological Survey, Saudi Geological Survey, Jeddah, Saudi Arabia

12 Department of Archaeology, College of Tourism and Archaeology, King Saud University, Riyadh, Saudi Arabia

13 School of Social Science, University of Queensland, St Lucia QLD 4072, Brisbane, Australia

14 Department of Anthropology, National Museum of Natural History, Smithsonian Institution 20013, Washington, DC, USA

15 Department of Archaeology and Anthropology, University of Calgary, 2500 University Drive, N.W., Calgary Alberta T2N 1N4, Canada

16 Australian Research Centre for Human Evolution (ARCHE), Griffith University, Brisbane, Australia

17 Institute of Prehistoric Archaeology, University of Cologne, Cologne, Germany 


\section{Introduction}

Taphonomic studies of fossil bone accumulations are powerful tools for elucidating the interactions between hominins, animals, and the environment and have been central in discussions surrounding early hominin evolution and human prehistory (Pante et al. 2012). Hominins and carnivores systematically process animal carcasses in ways that reflect species-specific feeding behaviors, order of access, and inter- and intra-taxon interactions (e.g., competition). Variations in social (e.g., group size) and ecological (e.g., season, prey availability) conditions further drive intraspecific variation in bone-accumulating and modifying behavior (Domínguez-Rodrigo 2001; Faith and Behrensmeyer 2006; Pobiner 2007; Lansing et al. 2009; Kuhn et al. 2010; Arriaza et al. 2016). The early recognition of this prompted a series of experimental and naturalistic studies that set out to identify how different bone accumulators and modifiers might be differentiated when studying fossil bone assemblages (e.g., Brain 1981; Blumenschine 1986 1988; Stiner 1990; Marean and Spencer 1991; Marean et al. 1992; Selvaggio 1994). These studies demonstrated that the kinds of prey and their ages (e.g., Stiner 1990; Bunn and Pickering 2010), skeletal part representation and fragmentation (e.g., Blumenschine 1986 1988; Marean and Spencer 1991; Marean et al. 1992), and the types of bone surface modifications, their locations, and frequencies (e.g., Blumenschine 1986 1988; Capaldo 1997; Domínguez-Rodrigo 1999) provide reliable insights into the agent(s) responsible for the accumulation of fossil bone assemblages. In addition to these more traditional methods, researchers are now employing a variety of sophisticated high-resolution imaging (e.g., Pante et al. 2017; Courtenay et al. 2019), multivariate analyses (e.g., Domínguez-Rodrigo and Yravedra 2009; DomínguezRodrigo and Pickering 2010), and machine learning (e.g., Harris et al. 2017; Domínguez-Rodrigo 2019; Moclán et al. 2020) techniques.

Large carnivores (e.g., lions, leopards, hyenas, wolves) have received considerable attention in taphonomic studies due to their overlapping trophic niche with Pleistocene hominins (Lyman 2018; Sala and Arsuaga 2018). In addition to an overlap in prey base, the bone-accumulating and modifying behavior of some large carnivores can generate bone assemblages that resemble those generated by hominins (i.e., equifinality), and distinguishing between these two accumulating agents can be challenging (Domínguez-Rodrigo et al. 2007; Lyman 2018). Studying and disentangling the fossil record therefore requires a good understanding of how modern carnivores accumulate and modify bone assemblages. Indeed, decades of naturalistic and experimental neo-taphonomic studies have shed considerable light on this topic and have become a cornerstone of paleoanthropological and paleontological research (Sala and Arsuaga 2018). However, these studies have been mostly restricted to relatively humid regions of Sub-Saharan Africa, Europe, and North and South America, and, as such, we have a limited understanding of the bone-accumulating and modifying behaviors of carnivores in arid regions like Arabia. Moreover, a considerable number of these studies have involved captive animals, which are known to modify bones quite differently to their wild counterparts (e.g., Gidna et al. 2013 2015; Sala et al. 2014). About two out of every five studies of spotted hyena (Crocuta crocuta), and about half of all studies of lion (Panthera leo) and wolf (Canis lupus), have involved captive animals (Lyman 2018).

Here, we conduct a detailed taphonomic analysis of a large wild carnivore-accumulated bone assemblage from the Umm Jirsan lava tube located in the Harrat Khaybar lava field, northern Saudi Arabia. Despite growing evidence for the importance of the Arabian Peninsula in human (and hominin) history and prehistory (e.g., Delagnes et al. 2012; Groucutt and Petraglia 2012; Groucutt et al. 2018; Stewart et al. 2020; Petraglia et al. 2015), only a single carnivore neo-taphonomic study has been conducted for the entire peninsula: a study of a small possible striped hyena accumulation from the coast of Qatar (Andrews 2008). Exploratory work has shown that bones in the Umm Jirsan lava tube system date from at least $\sim 4.5 \mathrm{ka}$ to recent times (Pint 2009). This and other similar sites, therefore, have potential to inform on paleoecology and key climatic and cultural changes-for example, the poorly understood transition from hunting to herding in northern Arabia. In fact, very little is known about the Holocene paleoecology of northern Arabia (Petraglia et al. 2020) and this is, in no small part, due to the extremely scant fossil record of the region. For example, in the Nefud Desert-an important region for understanding the Neolithization of northern Arabia-only four early- to mid-Holocene sites have yielded faunal remains (Guagnin et al. 2017 2021; Scerri et al. 2018; Groucutt et al. 2020). Moreover, the faunal material from these sites is extremely fragmentary, providing very little taxonomic insight. At the ORF2 site at Jebel Oraf, for example, of the $>1800$ recovered bone and tooth fragments, only 14 were identifiable to taxon (Guagnin et al. 2021).

The aims of this study are, therefore, to (a) identify the main bone-accumulating agent(s) at Umm Jirsan, (b) provide new data and a better understanding of the boneaccumulating behavior of carnivores in Arabia, and (c) see whether the assemblage holds valuable (paleo)ecological data in a region where bone and fossil preservation is otherwise exceptionally poor. 


\section{Study area}

The Umm Jirsan lava tube (25.5888 N, 39.7570 E; 1185 $\mathrm{m}$ a.s.1.) is situated in the Harrat Khaybar volcanic field approximately $125 \mathrm{~km}$ north of Medina, Saudi Arabia. The lavas that make up the Harrat Khaybar range in age from 5 million-years-old to the historic period (Roobol and Camp 1991; Groucutt 2020). The area can be broadly described as a rock and gravel desert with sparse soil cover, xeromorphic dwarf shrublands, and annual rainfall below $100 \mathrm{~mm}$ (Kürschner 1998).

The Umm Jirsan lava tube system consists of three segments separated by two collapses (Figs. 1A and 2), and it is currently the longest reported lava tube in Arabia with a horizontal passage length of $1481 \mathrm{~m}$ and typical height of 8-12 $\mathrm{m}$ (Pint 2009). The site was first investigated in 2007 by John Pint and members of the Saudi Geological Survey (Pint 2009). Bones, mostly representing carnivore accumulations, were found throughout and were particularly concentrated in the very western part of the system. Remains indicate the presence of "wolves, foxes, hyenas, rock doves, bats, sheep or goats, and swifts" and "growling" heard during the exploration of the site suggests that Umm Jirsan still serves as a den for carnivores (Pint 2009, para. 7). In addition to the animal bones, three human cranial remains were also discovered. Radiocarbon dating of the human remains returned ages of $150 \pm 30,3410 \pm 30$, and $4040 \pm 30{ }^{14} \mathrm{C}$ years BP, and dating of a large ungulate humerus returned an age of $2285 \pm 30{ }^{14} \mathrm{C}$ years BP (Table 1 ).

The 2019 study presented here was conducted in the very western part of system which Pint (2009) referred to as the "Wolf Den" due to the massive accumulation of bones there. The western passage can be further broken down into three broad bone accumulation sub-areas. The first area (referred to here as the "front chamber")—-encountered when moving through the western passage-comprises a massive accumulation of bones atop a large area of rock fall that rises a number of meters above the base of the lava tube (Fig. 2). This area is near completely covered in bones, including a number of distinct extremely dense concentrations which appear largely determined by the topography of the rock fall. Moving northward and over the rock fall, the lava tube wall forms an overhang, atop of which is a sparse accumulation of bone and a tight northward leading passage that

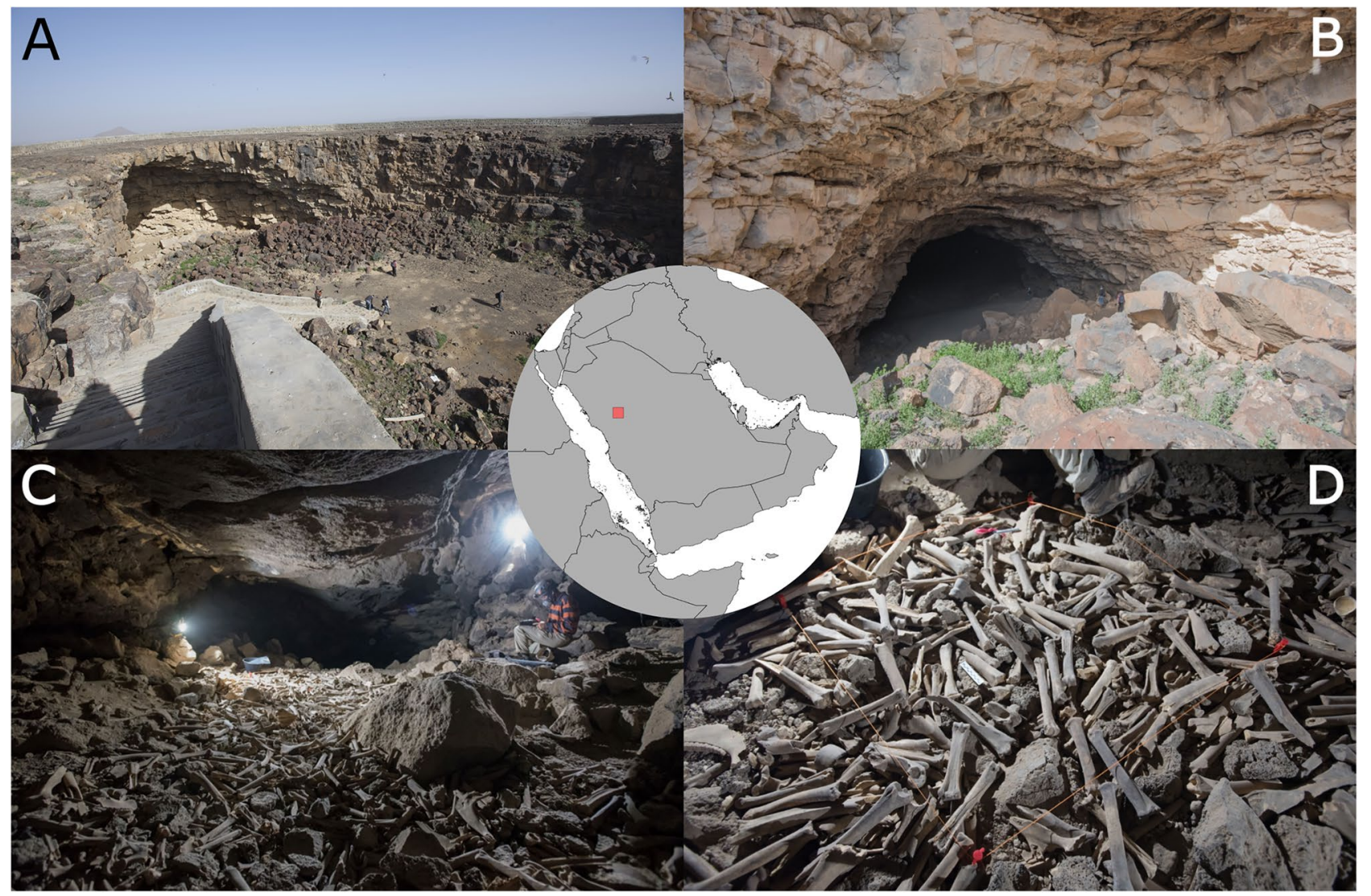

Fig. 1 Images of Umm Jirsan. A Entrance to the western passage and surrounding area. B Entrance to the western passage. Note the team members on the right hand wall for scale. $\mathbf{C}$ The back chamber in which the excavation was carried out. D Plotted sampling square before surface collection and excavation. Location of the site shown in the inset 
Fig. 2 Simple plan of the Umm Jirsan lava tube system. Redrawn after Pint (2009).

Survey by MA Al-Shanti, JJ

Pint, and M Moheisen. Map by MA Al-Shanti and JJ Pint. Area codes have been added for reference



also contains bone (referred to here as the "windy chamber"). Moving westward and below the overhang leads to a small distinct chamber at the very end of the western passage (referred to herein as the "back chamber") (Fig. 2). The back chamber contains an extremely dense accumulation of bones and is where the present study was conducted (Fig. 1C). In addition, a small number of bones were collected from other areas of Umm Jirsan, which are excluded from the main taphonomic analysis.

\section{Materials and methods}

A $1-\mathrm{m}^{2}$ excavation was carried out and positioned away from the edge of the cache in the back chamber, but near enough to exposed areas of the lava tube floor to allow researchers to carry out the investigations without disturbing the rest of the accumulation. All large bones lying on the surface were photographed in position, hand-collected, labelled, and then bagged. Once the surface material was cleared, the underlying sediment was excavated using small trowels and shovels, and described according to its texture (i.e., grain size, sorting, and colour). A simple stratigraphic log was constructed and is presented in Fig. 3. All sediment was sieved using a mesh size of $5 \mathrm{~mm}$, which was conducted off to the side of the cache in an area void of bones. All bone fragments, regardless of size, were collected and placed in marked bags. The excavation was conducted until reaching sterile sediments. These sediments included abundant small and large basalt blocks which appear to represent rock spalling/falling episodes. Therefore, the use of this part of the system as a carnivore den postdates this latest rock fall event. It is possible, however, that this chamber served as a carnivore den prior to this event and that continued excavations would have recovered additional material.

All recovered material (number of recovered specimens $($ NRSP $)=1917)$ was identified to the lowest taxonomic level possible, facilitated by relevant literature (e.g., Groves and Lay 1985; Harrison and Bates 1991) and osteological collections housed at the Royal Museum for Central Africa, Belgium. Specimen maximum length and width were collected using digital calipers and additional morphometric measurements taken following von den Driesch (1976). Standard quantitative units were used to report the results: NRSP, 
Table 1 AMS radiocarbon ages from Umm Jirsan calibrated using Calib (v. 8.20). Calibration done with IntCal20 (Reimer et al. 2020).

Radiocarbon dating analysis conducted at the SUERC Radiocarbon Laboratory, University of Glasgow

\begin{tabular}{|c|c|c|c|c|c|}
\hline Lab code & Layer & Material & AMS date (bp) & $\begin{array}{l}\text { Cal. BP } \\
95.4 \%(2 \sigma)\end{array}$ & Reference \\
\hline GdA-1156 & Surface & Bone (Homo sapiens) & $150 \pm 30$ & $\begin{array}{l}0-46(19.9 \%) \\
56-119(24.5 \%) \\
125-154(10.9 \%) \\
168-232(27.8 \%) \\
238-283(17.0 \%)\end{array}$ & Pint (2009) \\
\hline GdA-1158 & Surface & Bone (Homo sapiens) & $3410 \pm 30$ & $\begin{array}{l}3568-3721(95.0 \%) \\
3797-3819(5.0 \%)\end{array}$ & Pint (2009) \\
\hline GdA-1157 & Surface & Bone (Homo sapiens) & $4040 \pm 30$ & $\begin{array}{l}4419-4581(97.6 \%) \\
4599-4612(1.9 \%) \\
4772-4778(0.5 \%)\end{array}$ & Pint (2009) \\
\hline GdA-1159 & Surface & Bone (ungulate) & $2285 \pm 30$ & $\begin{array}{l}2157-2172(3.2 \%) \\
2174-2240(38.1 \%) \\
2300-2351(58.7 \%)\end{array}$ & Pint (2009) \\
\hline GU56831 & Surface & Bone (Homo sapiens) & $136 \pm 29$ & $\begin{array}{l}8-152(64.6 \%) \\
172-177(1.2 \%) \\
184-202(5.7 \%) \\
206-278(28.5 \%)\end{array}$ & This study \\
\hline GU56833 & Surface & Bone (Homo sapiens) & $2898 \pm 29$ & $\begin{array}{l}2952-3084(81.9 \%) \\
3088-3158(18.1 \%)\end{array}$ & This study \\
\hline GU56834 & Surface & Bone (Homo sapiens) & $3911 \pm 29$ & $\begin{array}{l}4246-4279(10.6 \%) \\
4284-4418(89.4 \%)\end{array}$ & This study \\
\hline GU55752 & Layer 1 & Tooth (Equus sp.) & $383 \pm 28$ & $\begin{array}{l}319-379(33.2 \%) \\
386-390(0.6 \%) \\
426-504(66.2 \%)\end{array}$ & This study \\
\hline GU56832 & Layer 1 & Bone (Homo sapiens) & $6001 \pm 29$ & $\begin{array}{l}6747-6769(6.5 \%) \\
6777-6905(87.7 \%) \\
6908-6936(5.7 \%)\end{array}$ & This study \\
\hline GU55753 & Layer 2 & Tooth (Equus sp.) & $373 \pm 28$ & $\begin{array}{l}318-393(42.0 \%) \\
425-499(58.0 \%)\end{array}$ & This study \\
\hline GU55754 & Layer 2 & Tooth (Equus sp.) & $4128 \pm 32$ & $\begin{array}{l}4529-4562(7.8 \%) \\
4565-4728(63.3 \%) \\
4749-4819(28.9 \%)\end{array}$ & This study \\
\hline GU55755 & Layer 3 & Tooth (Bos sp.) & $2824 \pm 31$ & $\begin{array}{l}2849-3005(97.5 \%) \\
3017-3030(1.3 \%) \\
3045-3056(1.2 \%)\end{array}$ & This study \\
\hline GU55756 & Layer 3 & Tooth (Equus sp.) & $2532 \pm 28$ & $\begin{array}{l}2495-2597(49.5 \%) \\
2616-2643(17.4 \%) \\
2686-2741(33.1 \%)\end{array}$ & This study \\
\hline GU56835 & Layer 3 & Tooth (Gazella sp.) & $3919 \pm 29$ & $4245-4421(100 \%)$ & This study \\
\hline GU56836 & Layer 3 & Tooth (Gazella sp.) & $3551 \pm 29$ & $\begin{array}{l}3722-3798(30.6 \%) \\
3819-3924(67.5 \%) \\
3949-3961(1.9 \%)\end{array}$ & This study \\
\hline GU55757 & Layer 4 & Tooth (Equus sp.) & $2544 \pm 31$ & $\begin{array}{l}2496-2596(42.6 \%) \\
2613-2641(15.6 \%) \\
2690-2747(41.8 \%)\end{array}$ & This study \\
\hline GU56837 & Layer 4 & Tooth (Capra sp.) & $2986 \pm 29$ & $\begin{array}{l}3067-3249(96.1 \%) \\
3301-3324(3.9 \%)\end{array}$ & This study \\
\hline
\end{tabular}

number of identified specimens (NISP), minimum number of elements (MNE), and minimum number of individuals (MNI). NISP was counted as the number of specimens identified minimally to a skeletal part, including midshaft and tooth fragments. MNE was calculated following an adapted version of Dobney and Rielly's (1988) zonation system and taken by tallying the "non-repeatable" elements (i.e., those with greater than $50 \%$ of the diagnostic zone present). MNI was calculated not only in the same way but by also taking into consideration the age (based on tooth wear, epiphyseal fusion, and bone texture in the case of neonates) and side (for bilaterally paired elements) of the animal. Quantitative units were normalized (\%NISP, \%MNE) by dividing all elements by the greatest values and multiplying the result by 
Fig. 3 Stratigraphic log of the Area A Umm Jirsan excavation

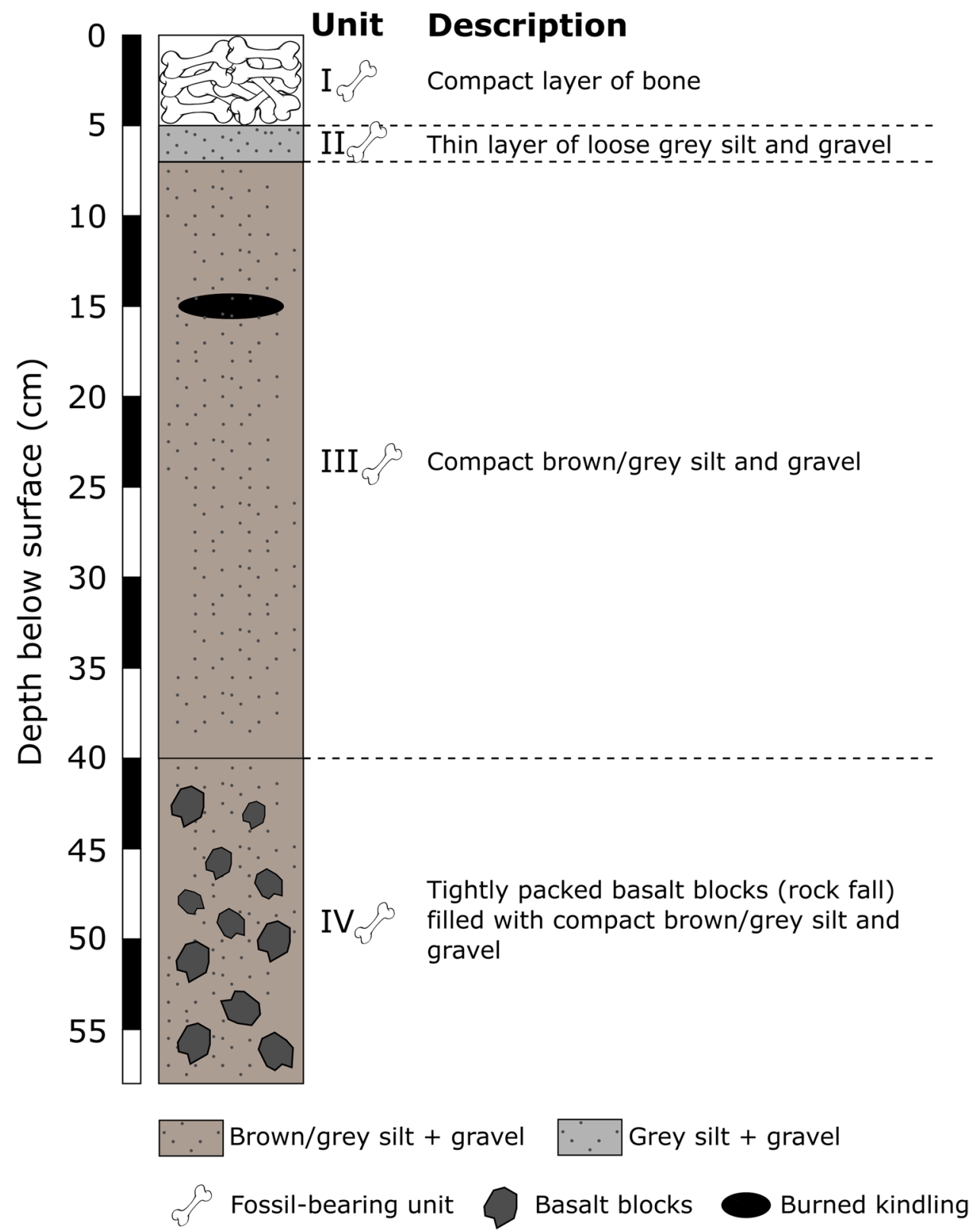

100 (following Binford 1984). Small unidentifiable fragments (less than $20 \mathrm{~mm}$ ) were recorded but excluded from the main analysis.

Each specimen was assigned an animal size class following a simplified version of Bunn's (1982) size class categories where small, medium, and large represent size classes I-II ( $<100 \mathrm{~kg})$, III-IV (100-340 kg), and IV (>340 kg), respectively. Average animal body masses were obtained from the PanTHERIA database (Jones et al. 2009). Long bone circumference completeness (\%) was recorded as type 1 (less than half), type 2 (more than half but not complete), or type 3 (complete) following Bunn (1982). Long bone fracture angle (oblique, right, oblique + right), outline (curved, transverse, intermediate), and edge (smooth, jagged) characteristics were recorded following Villa and Mahieu, (1991). Density-mediated attrition for ungulates was investigated by examining the relationship between skeletal part survivorship (\% MNE) and bone mineral density $\left(\mathrm{BMD}_{2} ; \mathrm{g} /\right.$ $\mathrm{cm}^{3}$ ) using values obtained from wildebeest and horse bone (Lam et al. 1999). To assess the differential destruction and transport of bone, we examined the relationship between $\% \mathrm{MNE}$ and the modified food utility index (MGUI) (Metcalfe and Jones 1988). Only high-survival elements were used in both these analyses (as per Faith and Gordon 2007).

Every specimen was examined by eye and hand lens (10-20 x) under different light exposures, and inconspicuous bone surface modifications were further examined by binocular microscopy (up to $80 \times$ ). Bones were inspected 
for preservation, weathering, chemical corrosion, staining, abrasion, and carnivore and rodent processing following established criteria (e.g., Behrensmeyer 1978; Maguire et al. 1980; Binford 1981; Fernández-Jalvo and Andrews 2016; for detailed discussion of the "Materials and methods" section, see Stewart et al. 2019). Carnivore tooth marks were classified into pits, scores, furrows, and punctures (following Binford 1981), their locations recorded (i.e., their anatomical location and whether they occurred in thick cortical or cancellous bone), and, in the case of pits and scores, measured using a digital caliper and magnifying lens $(10-20 \times)$ (following Andrés et al. 2012). Pits were measured for length (maximum dimension) and width (maximum dimension transversal to length), and scores measured for width (maximum dimension traversal to the long-axis of the score).

Animal age was estimated based on tooth eruption, replacement, and wear, and each specimen was placed in an age category based on potential ecological longevity (PEL) following Bunn and Pickering (2010): young individuals ( $<20 \%$ of PEL), early prime $(\sim 20-50$ of PEL), late prime ( $\sim 50-75 \%$ of PEL), and old individuals ( $>75 \%$ of PEL). Gazelle specimens were aged based on eruption and wear stages established for mountain gazelle (Gazella gazella) (following Munro et al. 2009) and a PEL of 11 years (Alados and Escós 1991). Caprid specimens were aged based on eruption and wear stages established from wild and domestic sheep/goat and a PEL of 10 years (following Payne 1973; Zeder 2006). Equid specimens were aged based on crown height (following Levine 1982) and a PEL of 20 years. Given that domestic animals and their wild progenitors often have significantly different lifespans, the PELs used here should be considered approximations of the PELs of the animals in this study.

Spearman's rank order $\left(r_{s}\right)$ coefficients were used to measure the strength of the linear associations between two variables. Statistical analyses were carried out in PAST (Hammer et al. 2001). Graphics were generated in PAST (Hammer et al. 2001) and RStudio (RStudio Team 2015).

\section{Results}

A total of 1917 bones and teeth were recovered from the den, of which 1073 were identifiable to a specific skeletal element (56.0\% of NRSP). The assemblage consists primarily of ungulates, most notably equids, and all portions of the skeleton are represented, albeit with significant differences in their frequencies. Bone preservation is highly variable, ranging from complete bones with adhered dehydrated soft tissue to highly degraded bone fragments and splinters. Thirteen samples (nine from the excavation and four from elsewhere in Umm Jirsan) were selected for radiocarbon dating and yielded median probability ages of between 6839 and 439 cal BP (all dates are calibrated BP), suggesting a long use of the lava tube system by carnivores (Table 1). Although the material is clearly somewhat mixed, it does appear that the trench preserves some degree of stratification, with all bones dated from the lower most layers (i.e., layers 3 and 4) dating to $>2400 \mathrm{BP}$ (Table 1). That said, larger and more informative remains (e.g., complete ungulate teeth) were targeted for radiocarbon dating, and it is clear that smaller, more fragmented material from these layers has migrated downwards from the overlying layers resulting in mixing. Dates obtained from the excavation and elsewhere in the lava tube suggest that there may have been a hiatus in den use after $\sim 2500 \mathrm{BP}$ up until more recent times, although more dates are needed to confirm this. And lastly, although this particular site may not be useful for addressing questions about specific timed events, it does preserve valuable paleoecological information, as we discuss below.

\section{Species representation}

A minimum of 40 individuals representing 14 taxa were recovered from the excavation (Table 2). Equids dominate the assemblage with 227 bones and teeth representing a minimum of 20 individuals (50\% of MNI) and at least two taxa: horse (Equus ferus) and ass (either the wild ass Equus africanus or the domestic donkey E. a. asinus). Only a single metacarpal is large enough to be confidently attributed to horse, whereas the remaining metapodials are all consistent with the smaller asses (Fig. 4). Likewise, all mandibular teeth possess the rounded, symmetrical metastylids and metaconids, V-shaped linguaflexids, and shallow buccal folds characteristic of asses (Chuang and Bonhomme 2019). Following suggestions by Eisenmann and Beckouche (1986) that wild and domestic asses may be differentiated on the morphology of their metapodials, we compared the Umm Jirsan metapodials to modern comparative material of African wild (E. africanus) and domestic (E. a. asinus) ass, the former being the only species of wild ass thought to have inhabited Arabia during the Holocene (Uerpmann 1987). The Umm Jirsan metacarpals are, as a group, comparatively large and are more consistent with African wild than domestic ass, although a couple of these fall outside the range of wild ass but are consistent with those of domestic ass (Figs. 4 and 5; Supplementary Tables 1, 2, 3).

Wild ass is thought to have been domesticated in northeast Africa sometime around $6500 \mathrm{BP}$ (Marshall and Weissbrod 2011). Their spread into Southwest Asia occurred about a millennium later, first appearing in the Levant around 5600-5100 BP, and later in Oman around the late 3rd to early 2nd millennium BC (Marshall 2007; Milevski and Horwitz 2019). African wild ass is known from a number of Holocene sites in southeastern Arabia (e.g., Uerpmann 1991; Cattani and Bökönyi 2002), where they persisted until 
Table 2 Taxonomic list from the excavation at Umm Jirsan

\begin{tabular}{|c|c|c|c|c|c|c|}
\hline Class & Order & Family & Taxon & Common name & NISP & MNI \\
\hline \multicolumn{7}{|c|}{ Reptilia } \\
\hline & Squamata & & Gen. et sp. indet & Lizard & 1 & 1 \\
\hline \multicolumn{7}{|l|}{ Aves } \\
\hline & & & Gen. et sp. indet & Bird & 6 & 1 \\
\hline \multicolumn{7}{|c|}{ Mammalia } \\
\hline & Hyracoidea & Procaviidae & Procavia capensis & Rock hyrax & 1 & 1 \\
\hline & Lagomorpha & Leporidae & Lepus capensis & Cape hare & 2 & 1 \\
\hline & Artiodactyla & Bovidae & Bos sp. & Cattle & 2 & 1 \\
\hline & & & Capra sp. & Caprine & 43 & 3 \\
\hline & & & Gazella sp. cf. G. dorcas & Dorcas Gazelle & 33 & 4 \\
\hline & & & Med-sized bovid & Med-sized bovid & 2 & 1 \\
\hline & & Camelidae & Camelus sp. & Camel & 16 & 2 \\
\hline & Perissodactyla & Equid & Equus africanus & Ass & 226 & 19 \\
\hline & & & Equus caballus & Horse & 1 & 1 \\
\hline & Carnivora & Hyaenidae & Hyaena hyaena & Striped hyena & 2 & 1 \\
\hline & & Canidae & Canis lupus & Wolf/dog & 16 & 3 \\
\hline & Primates & Hominidae & Homo sapiens & Human & 2 & 1 \\
\hline Total & & & & & 353 & 40 \\
\hline
\end{tabular}

perhaps as recently as $5000 \mathrm{BP}$ (Uerpmann 1991). Less is known about the situation in northern Arabia, but recently discovered rock art confirmed the presence of African wild ass in the region during the Holocene (Guagnin et al. 2018).
Considering the Holocene biogeography of equids in Arabia, the age of the Umm Jirsan material ( 7000 BP-present), and the size of the Umm Jirsan metacarpals, it is possible that both wild and domestic asses are represented at Umm Jirsan.
Fig. 4 Morphometric comparison of the Umm Jirsan equid metacarpals (MCIII) and comparative material of horse (Equus caballus), domestic ass (Equus africanus asinus), and African wild ass (Equus africanus). Measurements taken following von den Driesch (1976). Comparative data from http://www.vera-eisenmann. com/
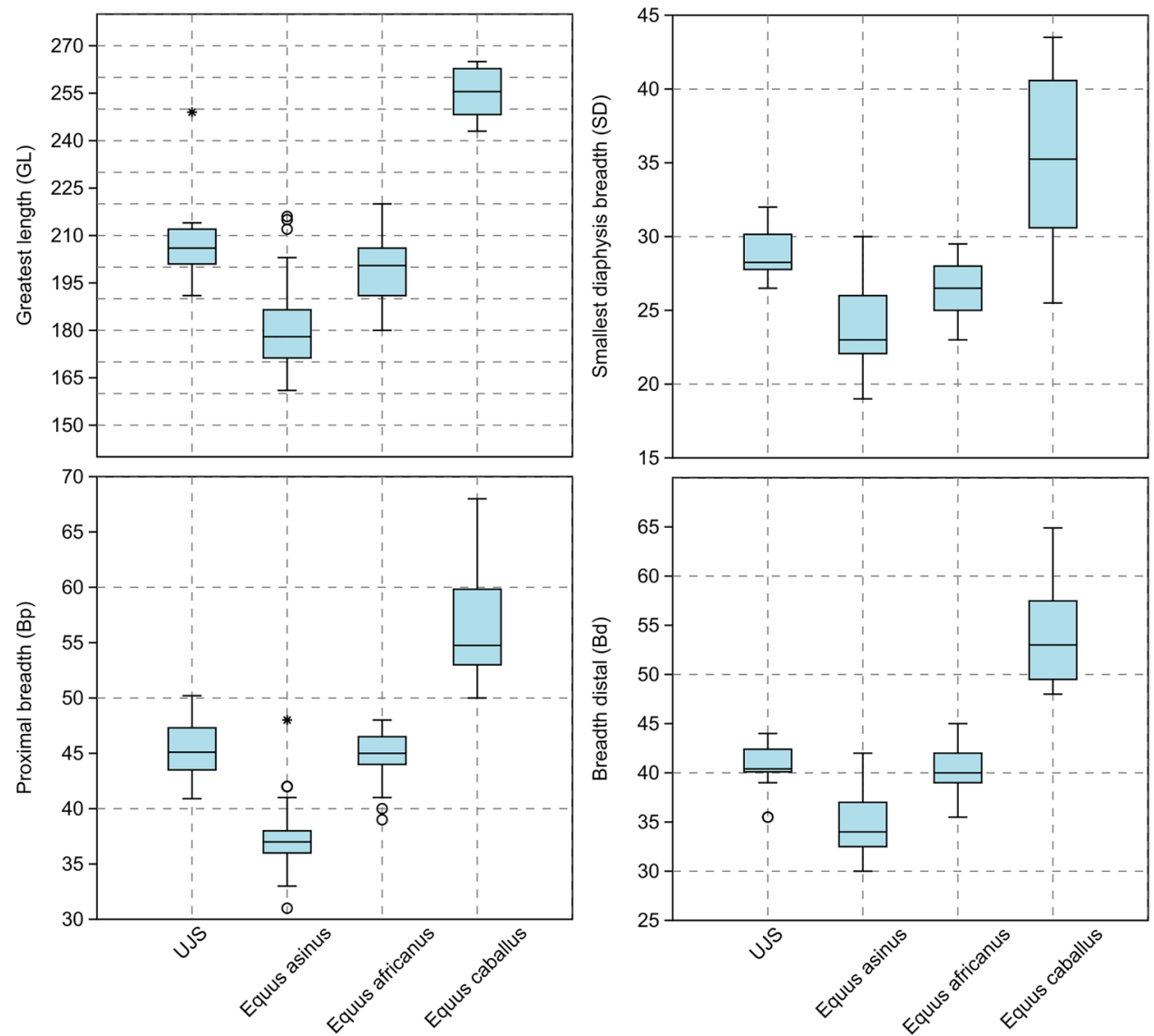
Fig. 5 Biplot comparison of the greatest length (GL) and distal breadth $(\mathrm{Bd})$ of the Umm Jirsan equid metacarpals (MCIII) and comparative material of horse (Equus caballus), domestic ass (Equus africanus asinus), and African wild ass (Equus africanus). Measurements taken following von den Driesch (1976). Comparative data from http://www.vera-eisenmann. com/

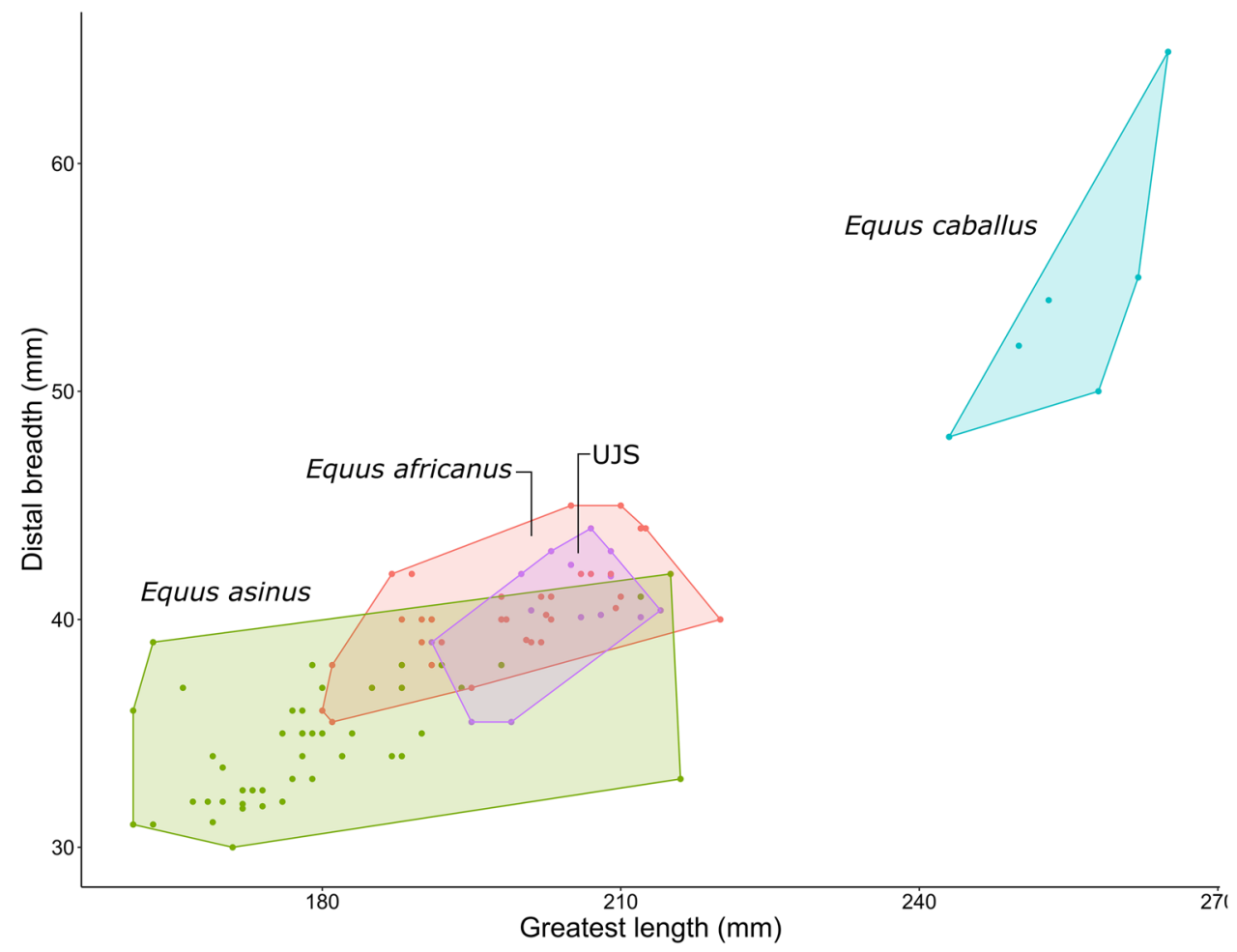

It is also worth noting here that some scholars believe there to have been a significant lag ( $>1000$ years) between domestication and morphological change among asses (Marshall 2007; Marshall and Weissbrod 2011), and, therefore, some of the Umm Jirsan equids may fall into this transitionary phase.

Gazelle is the second most abundant taxon with 33 remains representing a minimum of four individuals $(10.0 \%$ of MNI). Three species of gazelle can be found in Arabia today (Gazella gazella, Gazella dorcas, and Gazella marica) and at least one other species (Gazella bilkis; now extinct) occupied the region until relatively recently (Harrison and Bates 1991; Bärmann et al. 2013 and references therein). For most specimens, G. dorcas can be discounted based on tooth size alone (Supplementary Table 4). The m3 hypoconulids are shorter and more rounded, and the horns more inward pointing at their tips, than those of G. bilkis but are similar to G. gazella in both these features (Groves and Lay 1985). Horns are less lyrate than those of male G. marica but females of this species have straighter horns that may match some of those from Umm Jirsan (Harrison and Bates 1991). Taken together, the size and morphology of the Umm Jirsan material is most consistent with G. gazella, although without additional material it remains difficult to be certain, and, as with the equids, multiple taxa may be represented.

Forty-three caprid bones representing a minimum of three individuals ( $7.5 \%$ of MNI) can be attributed to either ibex (Capra ibex) or domestic goat (Capra aegagrus hircus). Ibex still inhabit parts of interior Arabia today, and domestic goat is an important livestock in the region. The domestication of goat occurred in the Zagros Mountains around 10,000 BP (Zeder and Hesse 2000), and their spread across Arabia had occurred by the sixth millennium BC (Makarewicz 2020 and references therein). Distinguishing between ibex and goat based on dentition alone can be difficult, and we follow earlier studies (e.g., Kerbis-Peterhans and Horwitz 1992; Kuhn 2005 ) by pooling these remains under "caprid."

Camel (Camelus sp.) is represented by 16 bones and a minimum of two individuals (5.0\% of MNI). Surprisingly, little is known about the history of the dromedary camel (Camelus dromedaries) and even less about its wild progenitor. Uerpmann (1987) suggested that the wild dromedary's range once included the deserts of eastern and central Arabia, and recently discovered ichnofossils (Stewart et al. 2020) and rock art depictions (Guagnin et al. 2018 2020) of wild camel confirm their presence in the peninsula's north. It is believed that the domestication of the dromedary occurred in southwestern Arabia sometime around 3400-2900 BP and that the extinction of the wild dromedary shortly followed (Uerpmann and Uerpmann 2012). Given the age of material at Umm Jirsan, it is possible that either forms are present.

Two teeth, a lower third premolar and an upper molar, can be attributed to $\operatorname{Bos}(2.5 \%$ of MNI), as well as an additional upper molar collected from outside the back chamber (Fig. 6). Cattle (Bos taurus) were first domesticated in the Euphrates between 11,000 and 10,000 BP (Helmer et al. 2005), and findings from southern Arabia suggest the arrival or local domestication of aurochs by about late 7 th/early 6 th 
Fig. 6 A-B Upper molars, Bos sp. C Right mandible, Gazella sp. cf. G. dorcas. D lower third premolar, Bos sp. E right mandible, Gazella sp. cf. G. dorcas. F Mandible, Procavia capensis. G Coprolites, Hyaena hyaena. H Maxilla, Capra sp. I Right maxilla, Camelus sp. J Mandible, Canis lupus. K Left mandible, Hyaena hyaena. Scale bars $10 \mathrm{~mm}(\mathbf{A}-\mathbf{G})$ and $30 \mathrm{~mm}(\mathbf{H}-\mathbf{K})$



millennium BC (Martin et al. 2009). Aurochs (Bos primigenius) - the ancestor to domestic cattle-were widely distributed across northern Africa, Southwest Asia, and Europe during the Holocene (Uerpmann 1987; Drechsler 2007; Zeder 2017). In Arabia, fossil remains are scarce outside of Yemen (see Drechsler 2007), but the presence of aurochs in northern Arabia has been recently confirmed from rock art engravings (Guagnin et al. 2015 2018). McCorriston and Martin (2009) suggested that given their ability to exploit a variety of grassland and woodland environments, aurochs may have been widely distributed across Arabia during the wet phases of the Holocene. The timing of their extinction in Arabia is unclear, but remains from nearby in Iran and Jordan date to as late as the Iron Age (see Uerpmann 1987). Again, whether the Umm Jirsan remains represent wild or domestic cattle is, at present, difficult to say, although the late age of the dated Bos sp. tooth is more suggestive of domestic animals given the dry conditions at the time.

Hyenas are represented by two juvenile mandibular specimens that possibly belong to the same individual
(2.5\% of MNI). These, and a number of other specimens found throughout Umm Jirsan but not retrieved as part of the excavation, have upper carnassials with short metacones and lower carnassials with a reduced but visible talonids, features that are characteristic of striped hyena (Hyaena hyaena) (Fig. 6). Hundreds of coprolites were present, and a small sample was collected and is currently undergoing micromorphological and biomolecular analysis. The coprolites are consistent with those of hyena in having a white appearance, crumbly texture, and globular morphology with either a single pellet or the appearance of two or three fused pellets (Fig. 6) (Sanz et al. 2016).

Canids are represented by 16 bones and a minimum of three individuals (7.5\% of MNI). Mandibles are larger than those of the Asiatic jackal (Canis aureus) and are consistent with those of the Arabian wolf (Canis lupus arabs) and probably domesticated dog (Canis lupus familiaris) (Fig. 6; Supplementary Table 5).

Microfauna are represented by few remains but include lizards, birds, hyrax (Procavia capensis), hare (Lepus 
Table 3 Complete skeletal inventory of small-, medium-, and largesized ungulates from the excavation at Umm Jirsan

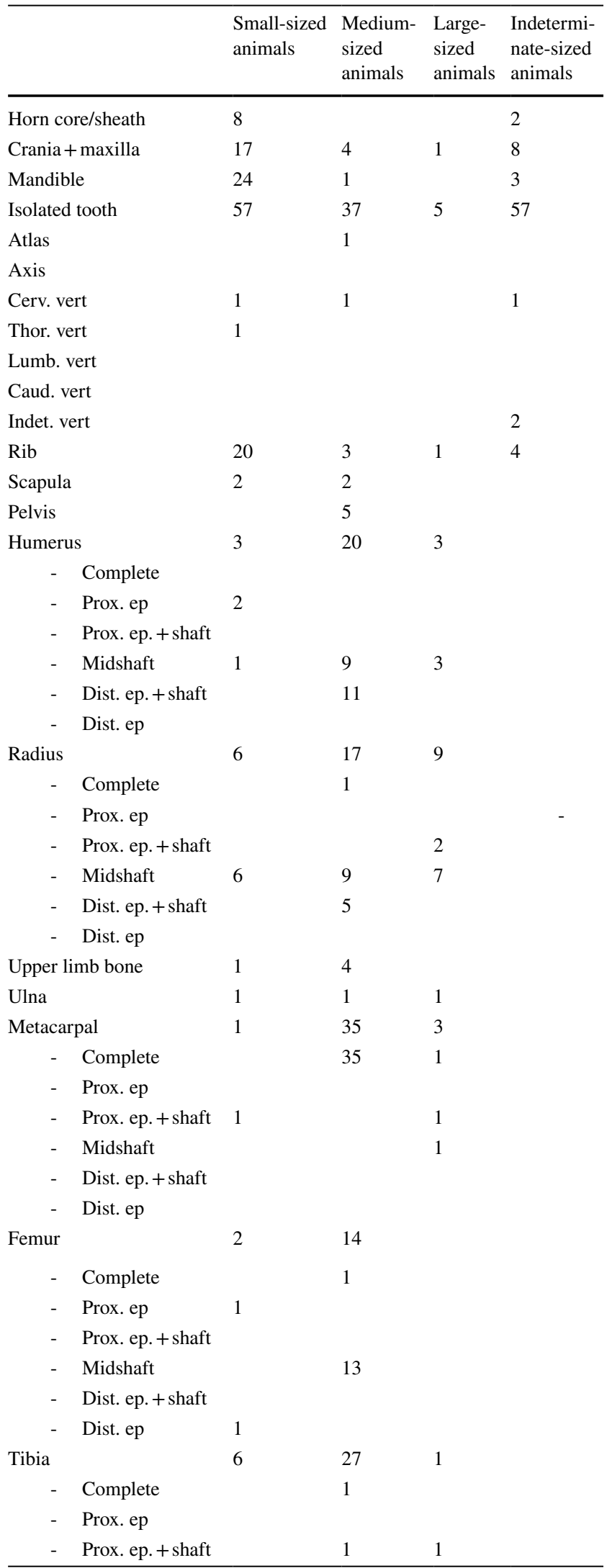

Table 3 (continued)

\begin{tabular}{|c|c|c|c|c|c|}
\hline & & $\begin{array}{l}\text { Small-sized } \\
\text { animals }\end{array}$ & $\begin{array}{l}\text { Medium- } \\
\text { sized } \\
\text { animals }\end{array}$ & $\begin{array}{l}\text { Large- } \\
\text { sized } \\
\text { animals }\end{array}$ & $\begin{array}{l}\text { Indetermi- } \\
\text { nate-sized } \\
\text { animals }\end{array}$ \\
\hline- & Midshaft & 3 & 11 & & \\
\hline- & Dist. ep. + shaft & 2 & 13 & & \\
\hline- & Dist. ep & 1 & 1 & & \\
\hline Metata & & 2 & 33 & 2 & \\
\hline & $\begin{array}{l}\text { Complete } \\
\text { Prox ep }\end{array}$ & 1 & 33 & & \\
\hline & Prox. ep. + shaft & & & 2 & \\
\hline $\begin{array}{l}- \\
- \\
-\end{array}$ & $\begin{array}{l}\text { Midshaft } \\
\text { Dist. ep. + shaft } \\
\text { Dist. ep }\end{array}$ & 1 & & & \\
\hline $\begin{array}{r}\text { Metap } \\
- \\
-\end{array}$ & $\begin{array}{l}\text { dial } \\
\text { Complete } \\
\text { Prox. ep }\end{array}$ & 2 & 21 & 4 & \\
\hline & Prox. ep. + shaft & & 1 & & \\
\hline - & Midshaft & 2 & 13 & 4 & \\
\hline- & Dist. ep. + shaft & & 4 & & \\
\hline- & Dist. ep & & 3 & & \\
\hline Astrag & & 1 & 19 & & \\
\hline Calcan & um & 3 & 4 & 1 & \\
\hline Carpal & arsal & 5 & 2 & & \\
\hline Sesam & & 1 & 1 & & \\
\hline Phalan & & & & & \\
\hline - & Proximal & 8 & & 1 & \\
\hline - & Intermediate & 2 & & & \\
\hline - & Distal & 1 & 3 & & \\
\hline - & Hoof & & 5 & & \\
\hline Sacrun & & & & & \\
\hline Long $b$ & one shaft & 260 & 123 & 27 & 120 \\
\hline Total & & 435 & 383 & 58 & 197 \\
\hline
\end{tabular}

capensis), and ostrich eggshell recovered from the front chamber. In addition, two human (Homo sapiens) crania fragments were recovered from the excavation, and a number of others were discovered in other parts of the Umm Jirsan system.

\section{Skeletal part representation}

Complete skeletal inventories by animal body size and taxa are presented in Table 3 and Supplementary Tables 6, 7, 8, 9, and 10, respectively. Except for two articulated equid astragali and calcanei, all skeletal elements are isolated. Despite efforts to identify midshaft fragments to a specific element, unidentifiable midshaft fragments dominate across all animal size classes (32-59\% of NISP) and particularly the small-size class (59\% of NISP). Fragile axial elements (e.g., vertebrate, ribs) and small compact bones (e.g., carpals, tarsals) are scarce and this is probably related to the 
ease with which carnivores process and consume these remains, although the former may be in part the result of selective transport (see below). The one exception to this is the abundant equid astragali, which may be too large and difficult to process or simply unappealing in terms of nutrition, and similar observations have been elsewhere (e.g., Pokines and Kerbis-Peterhans 2007).

Breaking down the skeletal part representation by taxa reveals that equids are overwhelmingly represented by complete metacarpals and metatarsals, probably reflecting their low nutrient yield to energy expenditure ratio (Fig. 7; Supplementary Table 9). Upper and intermediate limb bones are also well-represented but comprise mostly the denser and less nutritious distal and midshaft portions. Elements of the crania are underrepresented, suggesting that they were not transported to the den, having been exploited at the scavenge site. Similarly, camel is best represented by limb bones, notably the metapodials and radii, and the former is more fragmented than those of equids suggesting that they are easier to process and/or more nutritive (Fig. 7; Supplementary Table 8). Blumenschine and Madrigal, (1993) found that equid metapodials contained relatively little grease compared to bovids of similar sizes, and the same may hold true for camels given their bovid-like metapodial configuration. Gazelles and caprids are best represented by crania, mandibles, and isolated teeth, although abundant small-sized midshaft fragments suggest that this is more apparent than real (Table 3). Canids and hyenas are represented mostly by mandibles and isolated teeth (Supplementary Table 7). Few microfaunal remains were recovered but include elements of the crania, axial, and appendicular skeleton (Supplementary Table 10).

Several tests were carried out to assess the differential transport and destruction of bones at Umm Jirsan. First, the survivorship of equid high-survival skeletal parts (\%MNE) showed a positive and near-significant (Spearman's $\left.\mathrm{r}_{\mathrm{s}}=0.282, p=0.069\right)$ relationship with bone mineral density and a negative and significant relationship with MGUI (Spearman's $r_{s}=-0.703, p=0.007$ ) (Fig. 8). As such, and considering the scarcity of dense cranial elements, it appears that limb elements were preferentially transported to the den and that the more nutritious upper and intermediate limb bone portions more intensely processed. An excellent example of this is consumption of nearly all femur proximal and distal epiphyses to the exclusion of their less nutritive shafts. No correlation was found between small-sized ungulate (caprids + Gazella) skeletal part survivorship and bone mineral density (Spearman's $r_{\mathrm{s}}=0.213, p=0.175$ ) or MGUI (Spearman's $r_{s}=0.136, p=0.658$ ) (Fig. 8), although the sample size is small and dense mandible and midshaft fragments dominate the assemblage suggesting it has been significantly influenced by density-mediated attrition. In addition to these elements, the presence of a number of axial remains indicates a less biased transport strategy for smallsized animals.

\section{Bone surface modifications}

All bone surface modifications were calculated based on NISP values excluding isolated teeth and results by animal size class and trench layer are presented in Tables 4 and 5, respectively. Most bones were unweathered (86.6\%) and some were greasy to the touch. A small number of bones at Umm Jirsan (1.0\%) exhibit cracking and flaking consistent with weathering stages 1-2 suggesting that carnivores were, on occasion, transporting already defleshed bones to the den. Alternatively, these bones may have been transported to the den by porcupines (Hystrix), which are known to take over disused carnivore dens (Pokines and Kerbis-Peterhans 2007), are avid bone collectors, and show a predilection toward weathered bone (Brain 1980). In fact, two midshaft fragments are rodent gnawed and a number of porcupine quills were spotted throughout Umm Jirsan, although the latter may be the result of predation by carnivores. A significant number of bones exhibit rounding and polish (11.4\%) consistent with licking by carnivores, an activity common among young individuals in dens (Fernández-Jalvo and Andrews 2016). This was more frequently observed among medium-sized animal remains and may reflect a size preference among younger individuals: small-sized animal remains are more likely to be completely consumed or destroyed during processing, whereas large-sized animal remains may be too large to be efficiently handled.

Sixty-four bones (6.9\%) are corroded as a result of their deposition within a highly acidic environment and bacterial attack (Fig. 9). Many small bone fragments exhibit acid etching, rounding, and small perforations due to digestion. A number of specimens have been corroded by urine and feces (Fig. 9), which can produce conditions analogous to biologically active soils, especially when combined with high humidity and protection from subaerial environments (Fernández-Jalvo and Andrews 2016). Four teeth exhibit mosaic cracking of their dentine and erosion of their enamel, and further mechanical wear has eroded the already weakened dentine resulting in a "block-like" form. Twenty bones (2.2\%) have a white and chalky appearance, some of which are clearly the result of bacterial attack.

Forty-two percent of bone has evidence for carnivore processing, which includes gnaw marks, gastric etching, and rounding from licking. Gnaw marks take the form of tooth pits $(n=64)$, scores $(n=72)$, punctures $(n=2)$, and notches $(n=68)$. The frequency of gnawed bone is similar across the animal size classes (25.1-35.8\%) with the largesize class having the highest frequency $(35.8 \%)$, probably reflecting the greater effort required for the processing of 

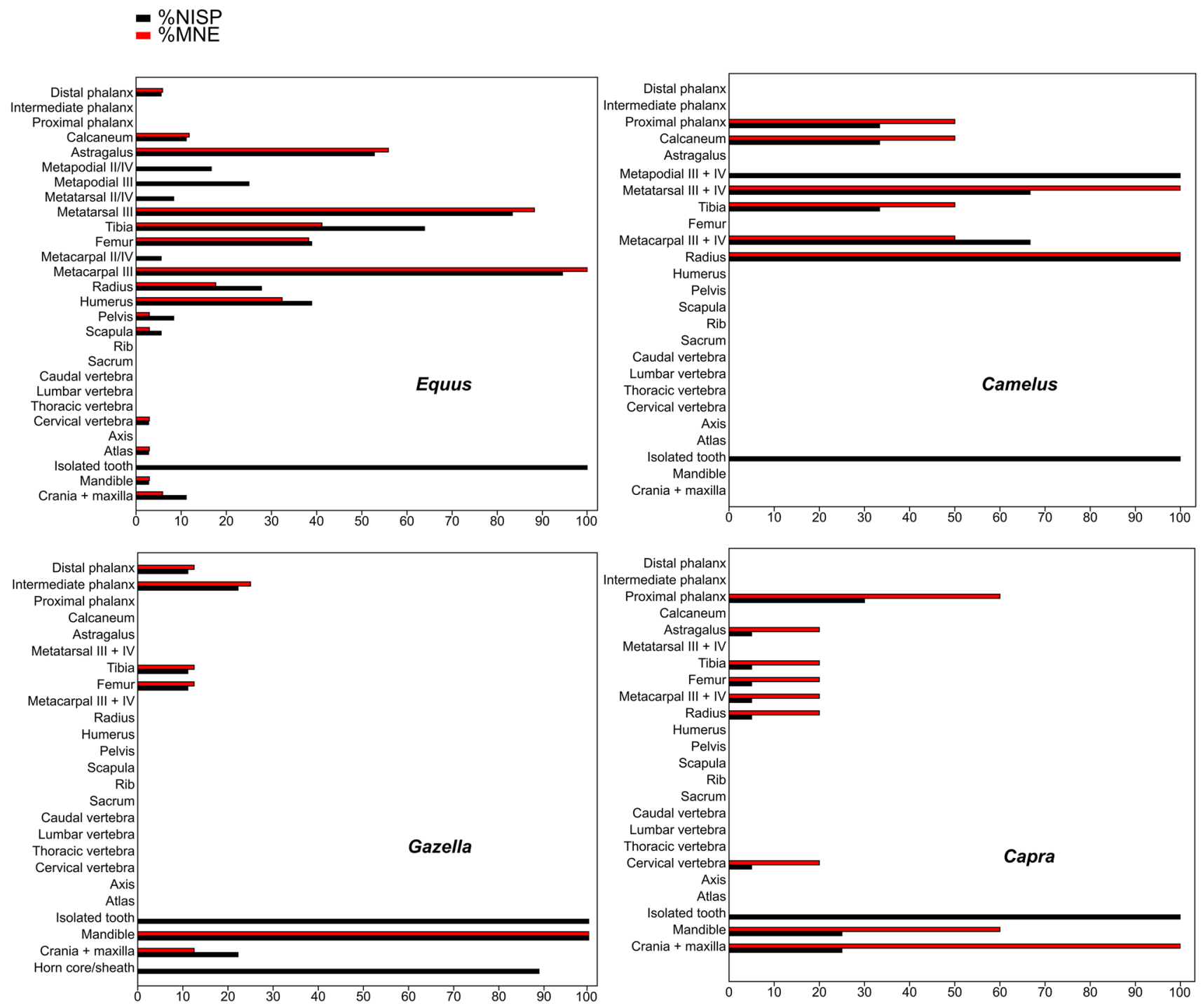

Fig. 7 Skeletal part representation of key taxa at Umm Jirsan

large animal remains. Looking specifically at small-sized animal long bones, the lower limb bones are most frequently gnawed (80\%), followed by the upper (40\%), and intermediate (25\%) limb bones (Supplementary Table 15 ). On the other hand, medium-sized animal upper limb bones are most frequently gnawed (53\%), followed by the intermediate (39\%), and lower (28\%) limb bones. This pattern of fewer gnaw marks moving down the limb is common in carnivore-accumulated assemblages as the upper limbs are more nutritious, and, therefore, more attractive to carnivores (Blumenschine 1986). The upper epiphyses are most commonly gnawed (17-40\%), followed by midshafts $(2-14 \%)$, and distal epiphyses (0-7\%). Again, this pattern is expected as the upper epiphyses typically contain abundant nutritive grease within their cancellous bone (Blumenschine 1988). Overall, tooth marks are quite small, being similar in size to those produced by dogs (Fig. 10; Table 6; Supplementary Tables 16,17), though it is important to remember that the tooth marks likely to include those of both juveniles and adults.

Additional bone surface modifications include a singlecut marked midshaft indicating that carnivores were, at least on occasion, scavenging from human refuse. A small pile of burnt kindling was also discovered during the excavationthat perhaps served as a torch by people investigating the cave-and has incidentally burnt a small number of bones $(1.1 \%)$. There is no other evidence for human use of the den.

\section{Bone fragmentation and fracture patterns}

The assemblage is heavily fragmented, as evidenced by the significant number of small midshaft fragments and 
Fig. 8 Caprid + Gazella and equid high-survival element $\% \mathrm{MNE}$ vs. bone mineral density $\left(\mathrm{BMD}_{2} ; \mathrm{g} / \mathrm{cm}^{3}\right)$ and the modified general utility index (MGUI). Full forms of abbreviations and raw data are provided in Supplementary Tables 11 and 12 . Bone mineral density data for equids and wildebeest from Lam et al. (1999). Modified general utility data from Metcalfe and Jones (1988)
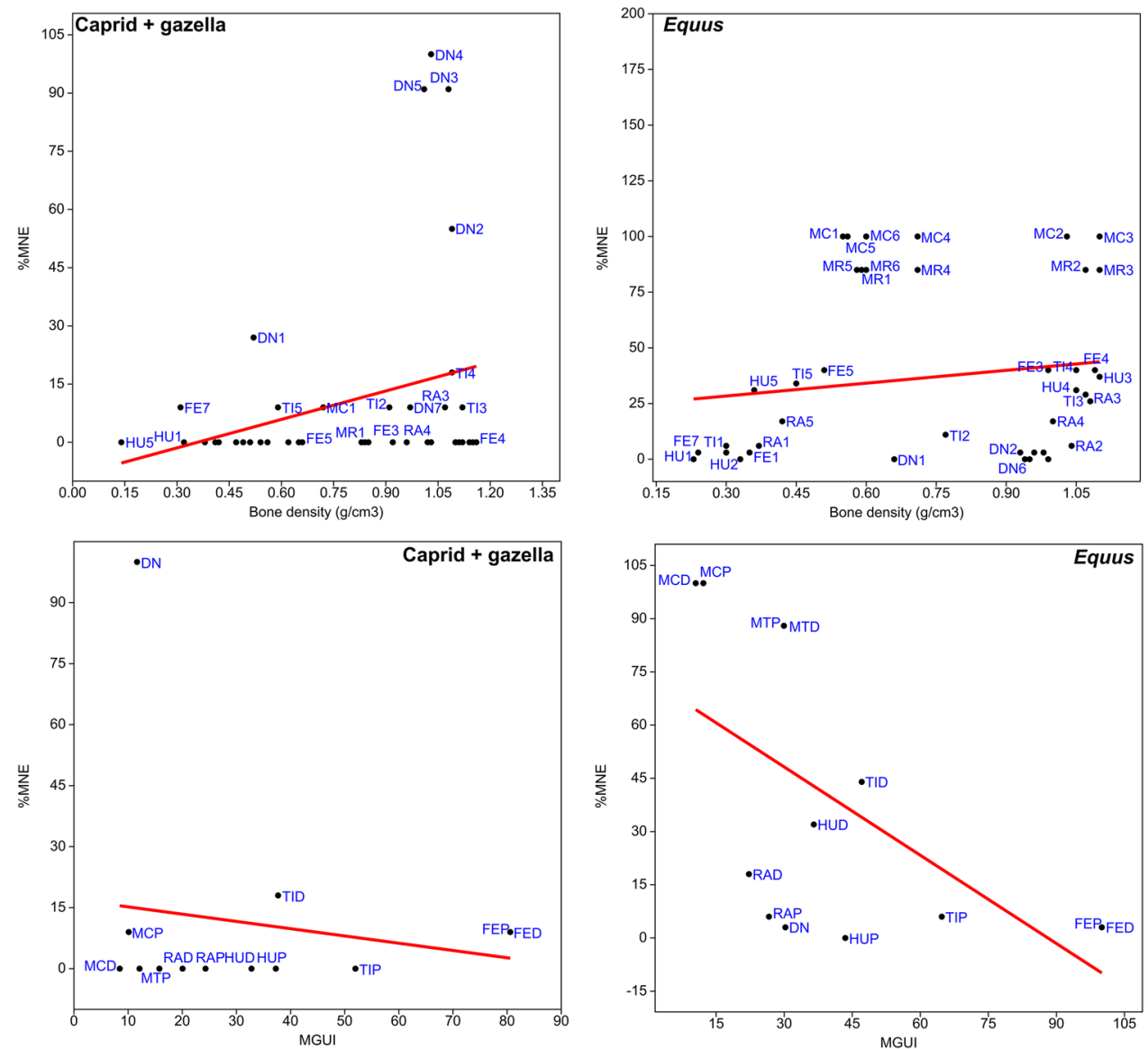

unidentifiable pieces of bone. Most limb bones are broken such that they retain less than half of their original circumference $(78.1 \%)$. Still, there is a significant number of limb bones that retain their complete circumference (19.9\%), although these consist mostly of complete equid metapodials. Small-sized animal limb bones are far more fragmented than those of medium- and large-sized animals reflecting the ease with which the Umm Jirsan carnivores were able to break open and consume the limb bones of smaller animals. Complete limb bones are, for the most part, confined to the uppermost layer, whereas layers $2-4$ are made up almost entirely of small bone fragments indicating that the smallest material has gravitated downwards in the sediment (Fig. 11).

The majority of long bone fragments exhibit oblique $(66.8 \%)$, curved (44.8\%), and smooth $(61.3 \%)$ fracture patterns consistent with the carnivore processing of fresh bone (Supplementary Table 18). Still, a significant number of bones exhibit right (18.7\%), transverse $(32.5 \%)$, and jagged $(38.6 \%)$ fracture patterns that are more consistent with the fracturing of dry bone. This is likely due to gnawing, trampling, and rock spall and would have been facilitated by chemical and bacterial corrosion that cause the loss of bone tissue and significantly weaken bone (Fernández-Jalvo and Andrews 2016).

\section{Mortality profiles}

Remains recovered not from the excavation were also included in the mortality analysis to boost the sample size. Of the eight caprid mandibles for which age groups could be confidently assigned, three were early/late prime aged (38\%), three were late prime aged (38\%), and two were old individuals (25\%) (Supplementary Table 19). For the gazelle mandibles, there was one juvenile/early prime aged (33\%), one early prime aged (33\%), and one old aged (33\%) (Supplementary Table 20). For equids, which is based mostly on isolated teeth, six were early prime aged (55\%) and five were old aged (45\%) (Supplementary Table 21).

\section{Discussion}

Here, we provided a detailed taphonomic analysis of a large carnivore-accumulated bone assemblage from the Umm Jirsan lava tube in the Harrat Khaybar, Saudi Arabia. The faunal material has accumulated over thousands of years, attesting to the excellent preservational conditions at Umm Jirsan and highlighting the potential for future research at this site, as well as at other nearby lava tubes. For reasons 
Table 4 Full results of the taphonomic analysis by animal size class (raw data presented in Supplementary Table 13)

\begin{tabular}{|c|c|c|c|c|c|c|}
\hline & & $\begin{array}{l}\text { Small-sized } \\
\text { animal }\end{array}$ & $\begin{array}{l}\text { Medium- } \\
\text { sized animal }\end{array}$ & $\begin{array}{l}\text { Large-sized } \\
\text { animal }\end{array}$ & $\begin{array}{l}\text { Indet.-sized } \\
\text { animal }\end{array}$ & Total \\
\hline NISP & $n$ & 435 & 384 & 58 & 197 & 1074 \\
\hline NISP (without isolated teeth) & $n$ & 378 & 347 & 53 & 145 & 923 \\
\hline \multicolumn{7}{|l|}{ Weathering } \\
\hline 0 & $\%$ & 97.1 & 88.2 & 98.1 & 51.0 & 86.6 \\
\hline 1 & $\%$ & 0.3 & 0.3 & 0.0 & 0.0 & 0.2 \\
\hline 2 & $\%$ & 0.0 & 2.0 & 0.0 & 0.0 & 0.8 \\
\hline 3 & $\%$ & 0.0 & 0.0 & 0.0 & 0.0 & 0.0 \\
\hline 4 & $\%$ & 0.0 & 0.0 & 0.0 & 0.0 & 0.0 \\
\hline 5 & $\%$ & 0.0 & 0.0 & 0.0 & 0.0 & 0.0 \\
\hline Indet & $\%$ & 2.6 & 9.5 & 1.9 & 49.0 & 12.5 \\
\hline \multicolumn{7}{|l|}{ Circ. comp } \\
\hline Type 1 & $\%$ & 95.1 & 50.8 & 74.5 & 100.0 & 78.1 \\
\hline Type 2 & $\%$ & 1.8 & 2.3 & 6.4 & 0.0 & 2.0 \\
\hline Type 3 & $\%$ & 3.2 & 47.0 & 19.1 & 0.0 & 19.9 \\
\hline Tooth-marked & $\%$ & 27.2 & 25.1 & 35.8 & 4.8 & 23.4 \\
\hline Black staining & $\%$ & 0.3 & 0.3 & 0.0 & 0.0 & 0.2 \\
\hline Excavation damage & $\%$ & 4.8 & 1.2 & 1.9 & 0.0 & 2.5 \\
\hline \multicolumn{7}{|l|}{ Abrasion } \\
\hline Striae & $\%$ & 0.5 & 0.0 & 0.0 & 3.4 & 0.8 \\
\hline Rounding & $\%$ & 6.9 & 15.6 & 7.5 & 28.3 & 13.7 \\
\hline \multicolumn{7}{|l|}{ Corrosion } \\
\hline Digestive & $\%$ & 6.9 & 0.6 & 0.0 & 11.0 & 4.8 \\
\hline Non-digestive & $\%$ & 1.3 & 2.6 & 0.0 & 4.1 & 2.2 \\
\hline Burning & $\%$ & 1.1 & 1.4 & 0.0 & 0.7 & 1.1 \\
\hline
\end{tabular}

discussed below, Umm Jirsan appears to have served primarily as a striped hyena den where carcasses and carcass parts were transported to and fed on. Previous neo-taphonomic studies of striped hyena in Africa and the Near East have provided important insights into the bone-accumulating and modifying behavior of this osteophagus carnivore (e.g., Kerbis-Peterhans and Horwitz 1992; Leakey et al. 1999; Kuhn 2005; Kempe et al. 2006; Schick et al. 2007; Fourvel et al. 2015). However, most of these are lacking in detailed taphonomic data or focus on only a few of the taphonomic variables that are of interest to most researchers (see Lyman 2018 Supplementary Information). Our detailed study bridges this gap and presents new data for the characterization of striped hyena behavior. First, we consider the ecology and feeding behavior of large carnivores in Arabia to demonstrate that Umm Jirsan likely served primarily as a striped hyena den before briefly discussing the implications of the present work for the study of prehistory and paleoecology.

\section{Accumulator(s) of the Umm Jirsan assemblage}

Known accumulators of macromammal remains in Arabia include red fox (Vulpes vulpes), striped hyena, Arabian wolf, Arabian leopard (Panthera pardus nimr), Asiatic cheetah
(Acinonyx jubatus venaticus), and, until historic times, lion (Panthera leo) (Harrison and Bates 1991). The large felids can be discounted as accumulators of the Umm Jirsan assemblage for a number of reasons. Firstly, unlike hyenids, and to a lesser extent canids, felids do not possess the skeletal and muscular apparatus for intensively processing dense skeletal remains (e.g., limb bone midshafts) of large animals like camels and equids (Domínguez-Rodrigo 1999; Gidna et al. 2015). Secondly, no skeletal or coprolitic remains of these animals were recovered at Umm Jirsan. And finally, leopards are restricted mostly to mountainous regions (Harrison and Bates 1991), whereas lions and cheetah do not den deep within caves (Laurenson 1993; Packer and Pusey 1997).

Red foxes, striped hyenas, and wolves are all known to occupy caves. Striped hyena appear to have a predilection for sheltering deep within complex cave systems (KerbisPeterhans and Horwitz 1992; Wagner 2006), whereas wolves and foxes tend to make greater use of cave entrances, rock shelters, and rocky crevices (Mech 1974; Harrison and Bates 1991). All three species show great variability in their diets, which includes the hunting and scavenging of domestic sheep and goats, gazelles, hares, rodents, birds, invertebrates, plant foods, and human refuse (Kruuk 1976; Macdonald 1978; Harrison and Bates 1991; Bothma 1998; 
Table 5 Full results of the taphonomic analysis by layer (raw data provided in Supplementary Table 14)

\begin{tabular}{|c|c|c|c|c|c|}
\hline & & Layer 1 & Layer 2 & Layer 3 & Layer 4 \\
\hline NISP & $n$ & 298 & 182 & 353 & 250 \\
\hline $\begin{array}{l}\text { NISP (without isolated } \\
\text { teeth) }\end{array}$ & $n$ & 284 & 156 & 261 & 216 \\
\hline \multicolumn{6}{|l|}{ Weathering } \\
\hline 0 & $\%$ & 99.6 & 99.4 & 91.6 & 55.6 \\
\hline 1 & $\%$ & 0.0 & 0.0 & 0.4 & 0.5 \\
\hline 2 & $\%$ & 0.0 & 0.0 & 0.4 & 2.8 \\
\hline 3 & $\%$ & 0.0 & 0.0 & 0.0 & 0.0 \\
\hline 4 & $\%$ & 0.0 & 0.0 & 0.0 & 0.0 \\
\hline 5 & $\%$ & 0.0 & 0.0 & 0.0 & 0.0 \\
\hline Indet & $\%$ & 0.4 & 0.6 & 6.5 & 41.2 \\
\hline \multicolumn{6}{|l|}{ Circ. comp } \\
\hline Type 1 & $\%$ & 28.9 & 97.0 & 97.4 & 97.8 \\
\hline Type 2 & $\%$ & 5.0 & 0.8 & 1.0 & 0.5 \\
\hline Type 3 & $\%$ & 66.2 & 2.3 & 1.4 & 1.6 \\
\hline Tooth-marked & $\%$ & 28.3 & 31.6 & 27.1 & 24.2 \\
\hline Black staining & $\%$ & 0.0 & 0.0 & 0.8 & 0.0 \\
\hline Excavation damage & $\%$ & 1.1 & 8.4 & 2.1 & 4.2 \\
\hline \multicolumn{6}{|l|}{ Abrasion } \\
\hline Striae & $\%$ & 0.0 & 0.0 & 0.0 & 3.2 \\
\hline Rounding & $\%$ & 9.9 & 15.4 & 8.0 & 24.5 \\
\hline \multicolumn{6}{|l|}{ Corrosion } \\
\hline Digestive & $\%$ & 0.4 & 10.9 & 8.4 & 1.9 \\
\hline Non-digestive & $\%$ & 0.0 & 4.5 & 4.6 & 0.5 \\
\hline Burning & $\%$ & 0.0 & 1.3 & 1.25 & 1.7 \\
\hline
\end{tabular}

Leakey et al. 1999; Wagner 2006). Larger livestock such as adult camels, cattle, and donkey are too large to be hunted and must be scavenged (Harrison and Bates 1991; Bothma 1998). Striped hyenas are also frequent looters of human grave sites, and human cranial remains are a common feature of striped hyena dens (e.g., Horwitz and Smith 1988; KerbisPeterhans and Horwitz 1992; Leakey et al. 1999).

Despite a similar dietary breath, the feeding behavior of wolves on the one hand, and of striped hyena and foxes on the other hand, differs in important ways for the present study. Wolves mostly consume their prey at kill/ scavenge sites, and the feeding of pups typically involves the regurgitation of previously ingested meat (Mech 1974; Domínguez-Rodrigo et al. 2012). The transport of bones to den sites occurs very sporadically such that even in multigenerational dens, bones are only sparsely scattered about and rarely form conspicuous accumulations (DomínguezRodrigo et al. 2012). Taphonomic studies of wolf feeding behavior have also shown that wolves tend not to disperse the bones of large animals more than a few hundred meters from kill/scavenge sites (e.g., Yravedra et al. 2011 2012; Fosse et al. 2012).
In contrast, striped hyena and red foxes are avid hoarders of bone which they transport to dens to be eaten, provisioned for periods of food scarcity, or to be processed and fed to young (Kruuk 1976; Rieger 1979; Krajcarz and Krajcarz 2014; Yravedra et al. 2014). It is this behavior that produces the significant accumulations of bones observed in and around the dens of these animals (e.g., Kerbis-Peterhans and Horwitz 1992; Kuhn 2005; Kempe et al. 2006; Schick et al. 2007; Krajcarz and Krajcarz 2014; Yravedra et al. 2014). There are, however, key differences in the feeding behaviors of these two species that are important to the present study. The first of these relates to their ability to transport remains of large animals. Striped hyenas have powerful neck and masticatory muscles that enable them to transport large carcasses and carcass parts over considerable distances (Buckland-Wright 1969). Kruuk, (1976), for example, observed a striped hyena carry an entire wildebeest leg over a distance of $2 \mathrm{~km}$, and similar observations have been reported by others (Pickering 2002). In fact, this appears to be a common behavior among striped hyena, as evidenced by the overabundance of medium- and large-sized ungulate limb bones in the dens of this species (e.g., Skinner et al. 1980; Kerbis-Peterhans and Horwitz 1992; Kuhn 2005; Schick et al. 2007; Monchot and Mashkour 2010). Foxes, on the other hand, are much smaller and are more restricted with what they can physically carry, and even small ungulates like sheep, goat, and pigs must be mostly dismembered prior to transport (Yravedra et al. 2014; Arilla et al. 2018). In addition to small ungulates, fox dens are typically characterized by an abundance of small animals such as birds, leporids, rodents, and foxes (Yravedra et al. 2014; Arilla et al. 2018).

The second key difference between these two species relates to their ability to intensively process ungulate remains. Striped hyenas have a large sagittal crest and powerful masticatory muscles that enable them to efficiently break open the limb bones of animals much larger than themselves, which they do to gain access to the rich marrow within (Buckland-Wright 1969; Wagner 2006). A byproduct of this behavior is that striped hyena assemblages are often dominated by abundant small-, medium-, and large-sized animal midshaft fragments (Kuhn 2005; Schick et al. 2007). Foxes, on the other hand, do not possess this ability, and in fox-accumulated assemblages, even small-sized ungulate limb bones are almost always complete, with damage being restricted mostly to the gnawing and furrowing of the midshaft and epiphyses (Krajcarz and Krajcarz 2014; Yravedra et al. 2014; Arilla et al. 2018).

Taken together, the large size of the assemblage, the overabundance and intensive processing of ungulate limb bones, abundant hyena coprolites, and presence of juvenile hyena and human cranial remains suggest that Umm Jirsan served primarily as a striped hyena den, and, on occasion, as a maternal den. That said, taphonomic histories are usually 
Fig. 9 Examples of corroded bone. A Digestive corrosion of small bones. B Block-like corrosion of equid teeth dentine. $\mathbf{C}$ Non-digestive acid corrosion. D Carnivore gnawed and bacterially attacked midshaft fragment. Scale bar $=10 \mathrm{~mm}$

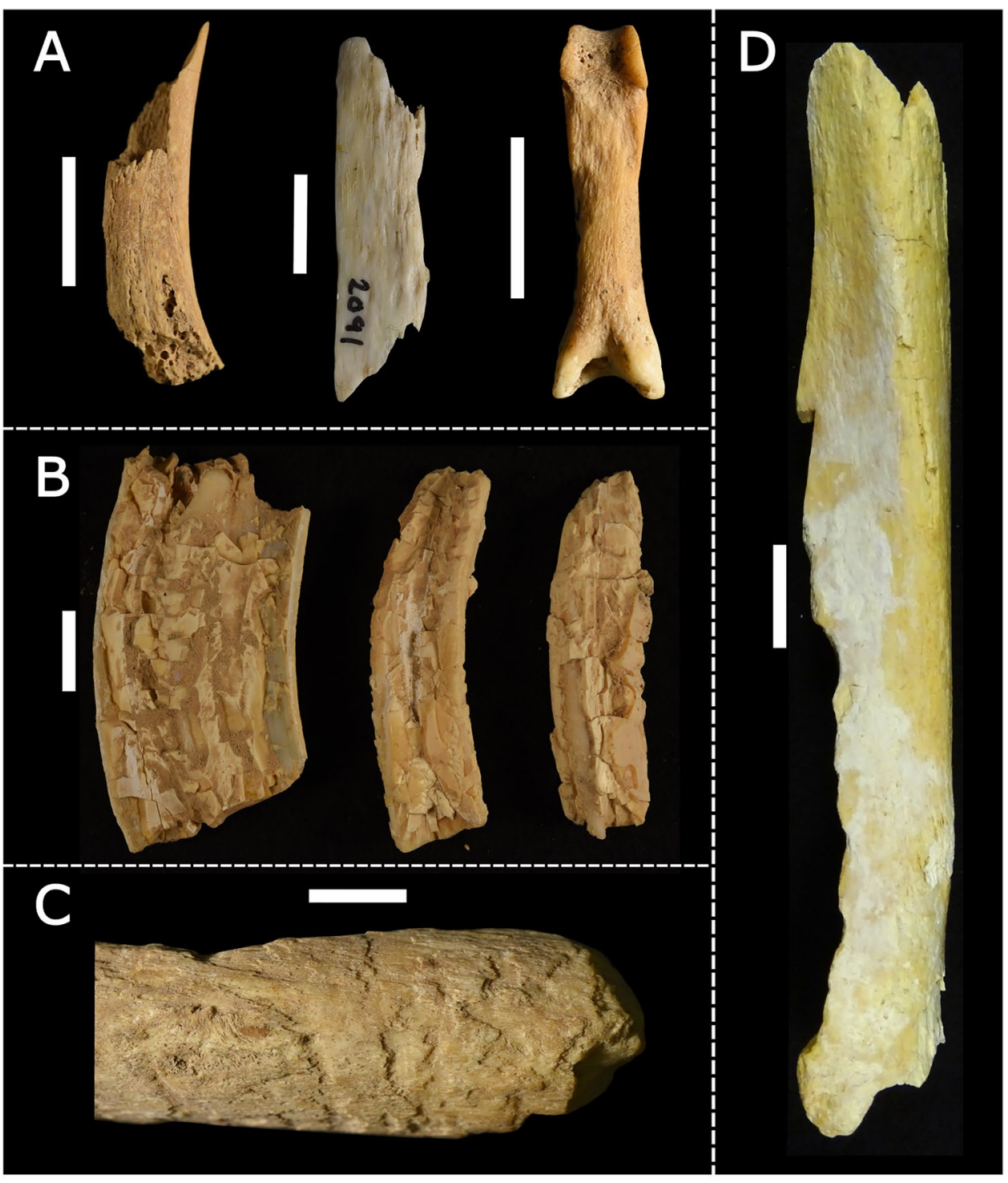

complex and other carnivores may have contributed in part to the studied assemblage, either by importing bones or by simply modifying bones already present in the den. Foxes, for example, may have contributed to the few microfauna represented at the site (but see below), and small microfauna accumulations nearer the entrance of Umm Jirsan and situated in front of small crevices in the lava tube wall are probably fox accumulations.

\section{Striped hyena feeding behavior at Umm Jirsan}

The representation of small-sized animal skeletal parts at Umm Jirsan suggests a less biased transport strategy of these animals compared to that of medium- and large-sized ungulates, likely reflecting the ease with small animals can be transported whole or in large portions. Once in the den, small animal carcasses are intensively processed with often only the mandible and isolated teeth surviving. Limb bones are intensely gnawed, producing significant quantities of bone splinters, and much of the rest of the skeleton may be consumed and completely destroyed during digestion. Identifiable microfauna remains do occasionally survive hyena digestion (Sanz et al. 2016), and this may account for the few microfauna represented at Umm Jirsan, about half of which show evidence for digestive corrosion. Mediumand large-sized ungulates are overrepresented by limb bones suggesting the preferential transport of these nutritious elements. The more nutritious upper and intermediate limb elements are intensively processed and this typically involves the fragmentation of the midshaft, consumption of the proximal epiphysis, and, to a lesser extent, consumption of the distal epiphysis. The less nutritious lower limb elements-which at Umm Jirsan comprises mostly equid metapodials - are far less intensely processed and the majority of 

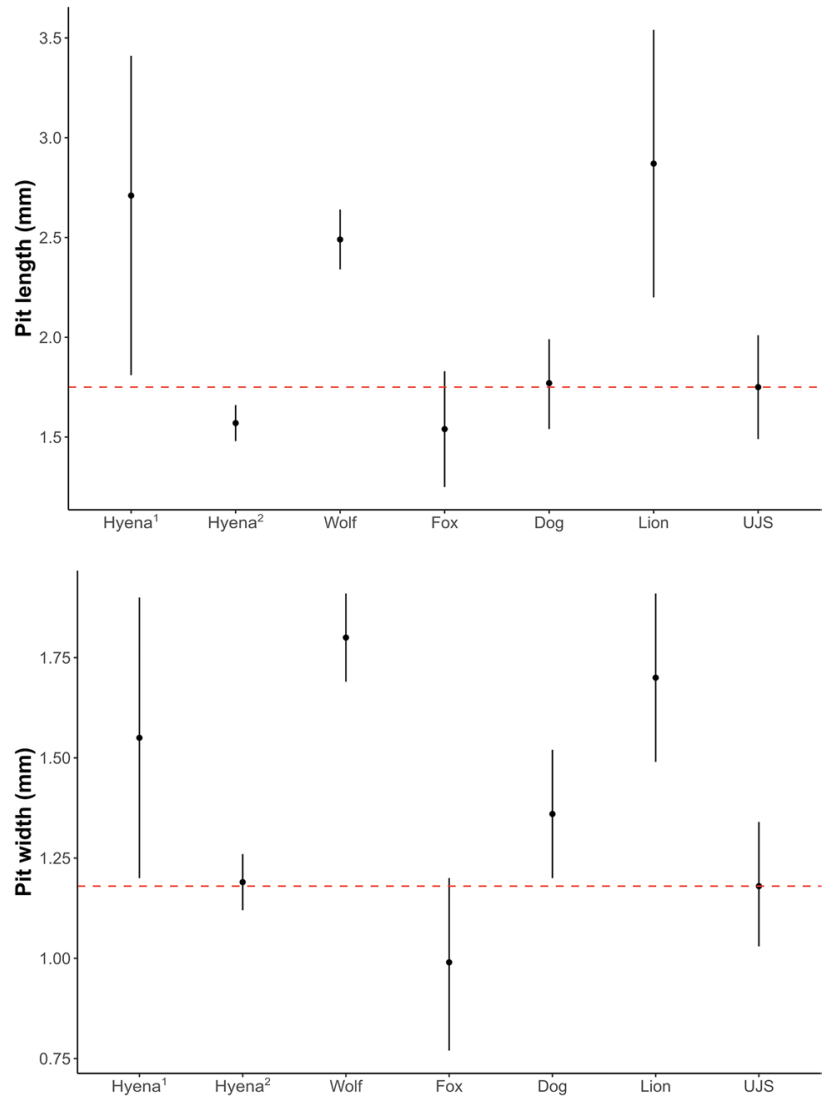

Fig. 10 Carnivore tooth pit and score length and width data for compact bone only (mean $\pm 95 \% \mathrm{CI}$ ). Descriptive statistics provided in Table 6 and raw data in Supplementary Tables 16 and 17. Comparative data from Andrés et al. (2012). The hyena ${ }^{1}$ sample comprises an assemblage processed by adult spotted hyena, whereas the hyena ${ }^{2}$ sample likely comprises an assemblage processed by juvenile spotted hyena. Dotted red line marks the Umm Jirsan mean

these elements are complete. Still, a number of metapodials are fragmented indicating that striped hyenas are capable of breaking open these very dense elements. The degree to which these elements are processed probably depends on competition and resource availability, as has been observed among spotted hyena in the Amboseli National Park, Kenya (Faith and Behrensmeyer 2006). A single-cut marked bone suggests that hyenas were, on occasion, scavenging human refuse- a behavior that is common among modern striped

Table 6 Tooth pit and score summary statistics (compact bone only). Raw data provided in Supplementary Tables 16 and 17

\begin{tabular}{lllll}
\hline & $\begin{array}{l}\text { Mean } \\
(\mathrm{mm})\end{array}$ & $\begin{array}{l}\text { Range } \\
(\mathrm{mm})\end{array}$ & $\begin{array}{l}\text { 95\% CI } \\
\text { lower }\end{array}$ & 95\% CI upper \\
\hline Pit length & 1.75 & $0.8-4.4$ & 1.49 & 2.01 \\
Pit width & 1.18 & $0.6-2.9$ & 1.03 & 1.34 \\
$\begin{array}{l}\text { Score } \\
\text { width }\end{array}$ & 0.93 & $0.4-3.3$ & 0.73 & 1.14 \\
\hline
\end{tabular}

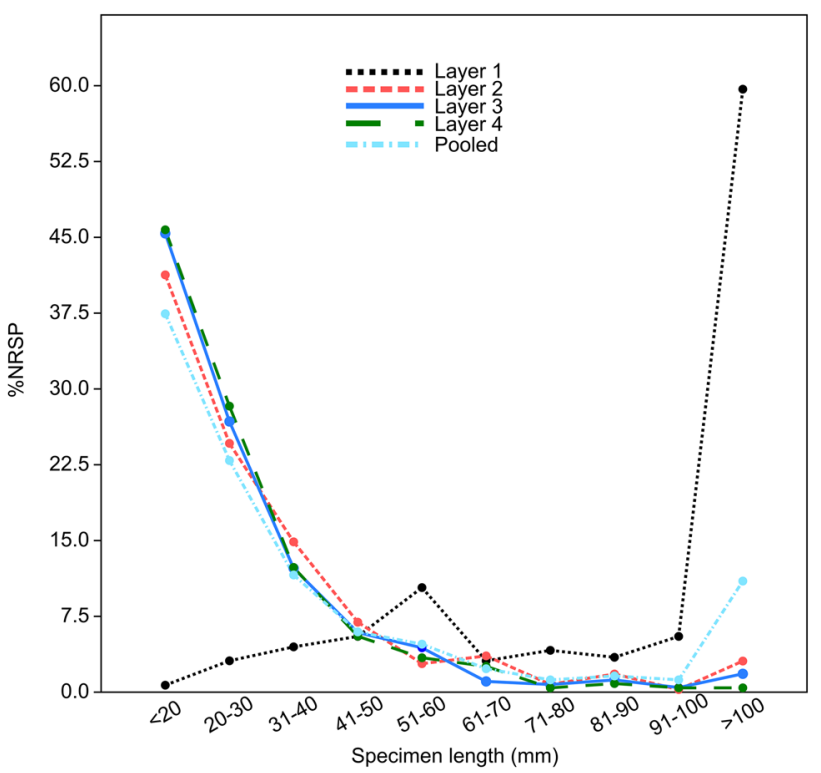

Fig. 11 Specimen length profile

hyena (Kruuk 1976; Macdonald 1978; Leakey et al. 1999; Wagner 2006) - and butchered bones have been recovered from striped hyena dens in Jordan (Schick et al. 2007).

In fact, modern striped hyena populations may be largely synanthropic (i.e., dependent on humans), as suggested by the abundant livestock in their diets and home ranges nearing areas of human habitation (Kruuk 1976; Skinner and Ilani 1979; Skinner et al. 1980; Kerbis-Peterhans and Horwitz 1992; Hofer 1998; Leakey et al. 1999; Kuhn 2005; Kempe et al. 2006; Schick et al. 2007; Monchot and Mashkour 2010; Singh et al. 2010; Fourvel et al. 2015). To test whether striped hyena accumulations reflect the dominative livestock practices in the region, we plotted the \%NISP of key taxa from five striped hyena dens (Fig. 12). In areas where caprid herding is widely practiced, caprids dominate striped hyena dens (as at Arad and Datagabou), whereas in areas known for camel herding, camels dominate striped hyena dens (as at Dhahik). At Umm Jirsan, asses dominate the assemblage. And while it is possible that both wild and domestic asses are represented at Umm Jirsan, this hints at a strong focus on the use of domestic asses over the past few thousand years in the Harrat Khaybar region.

Carnivores also form an important part of striped hyena diets (Fig. 12). Striped hyena have been observed chasing small carnivores such as bat-eared fox, domestic cats, and cheetah cubs (Kruuk 1976; Skinner and Ilani 1979), and wolves, dogs, and jackals may be hunted or killed during confrontations over carcasses (Leakey et al. 1999). While it is possible that wolves occupied and died "naturally" at Umm Jirsan, their mandibles exhibit damage that is similar of those found in striped hyena dens elsewhere-i.e., the coronoid process, condyle, and ramus have been consumed but 

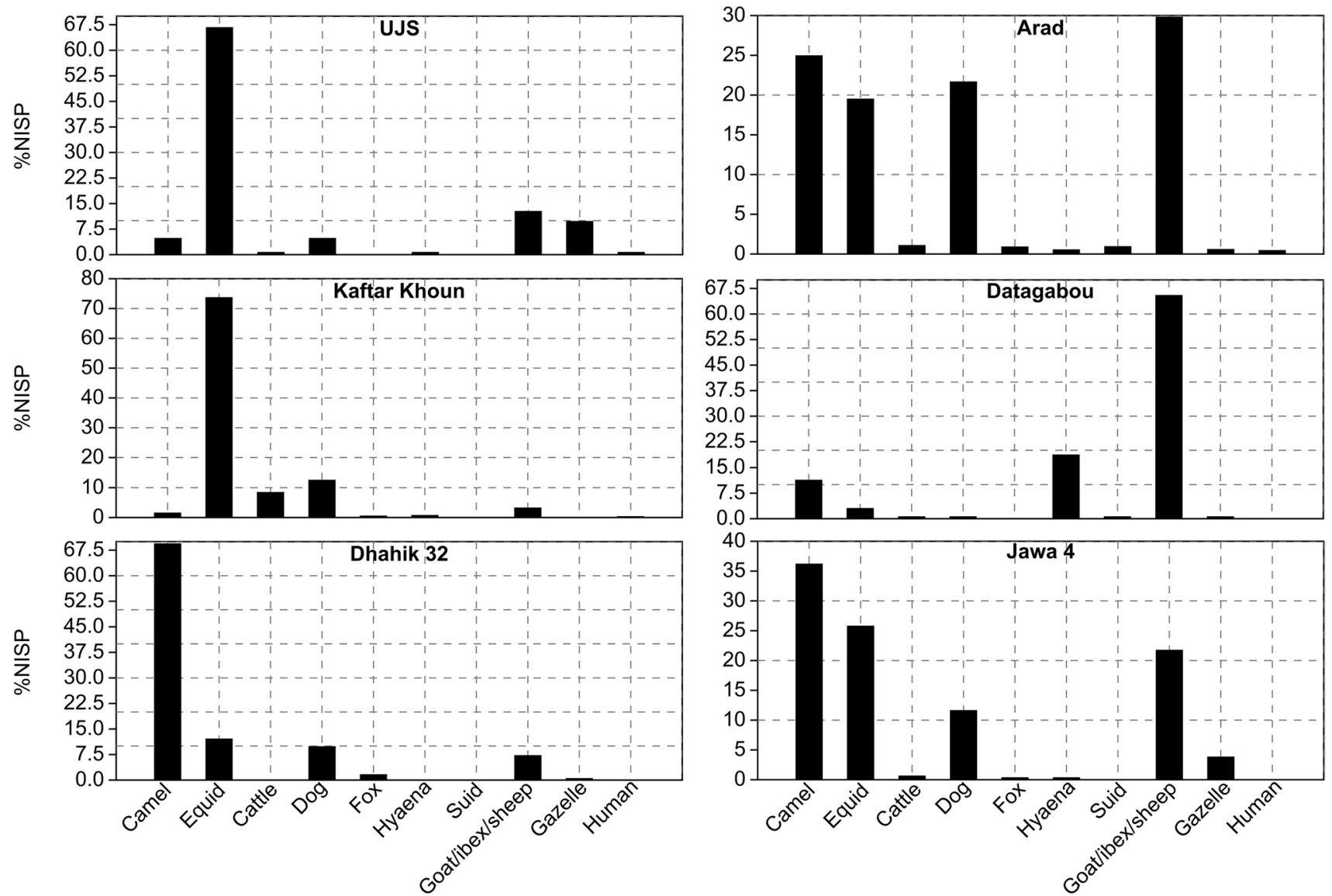

Fig. $12 \%$ NISP data of key taxa from large (> 100 NISP) striped hyena den assemblages. Data from Kerbis-Peterhans and Horwitz, (1992), Kuhn et al. (2010), Monchot and Mashkour, (2010), and Fourvel et al. (2015)

with no evidence of damage to the rest of the mandible (c.f., Kerbis-Peterhans and Horwitz 1992). Cruz-Uribe (1991) and Pickering (2002) suggested that striped hyena-accumulated and human-accumulated assemblages may be differentiated by the relative abundance of carnivore remains in the dens of the former (carnivore: ungulate + carnivore MNI). This ratio at Umm Jirsan is relatively low (12\%), supporting Kuhn et al.'s (2010) findings that carnivore remains are often rare in striped hyena dens. This ratio, however, may be a useful criterion for distinguishing between striped, spotted, and brown hyena accumulations (Fig. 13). Carnivore remains are rare in spotted hyena dens (interquartile range (IQR): $0.0-7.9 \%$ ), more common in striped hyena dens (IQR: 9.0-24.7\%), and more common again in brown hyena (Hyaena brunnea) dens (IQR: 16.7-72.6\%). Although, caution should be taken here given that carnivore remains appear to have been more common in Pleistocene-aged spotted hyena dens in Europe (Arsuaga et al. 2012; Sala et al. 2020) suggesting perhaps a through-time change in spotted hyena denning and feeding behavior or, alternatively, a difference in these behaviors between European and African spotted hyena.
A second potentially useful criterion for distinguishing between hyena accumulations involves the frequency of small compact bones (e.g., sesamoids, carpals, tarsals). In line with earlier studies of striped hyena accumulations (Cruz-Uribe 1991; Kuhn et al. 2010), small compact bones are scarce (6\% of postcranial NISP) at Umm Jirsan. Kuhn et al. (2010) found that between 14 and 34\% of spotted hyena bone accumulations consisted of small compact bones, whereas in striped and brown hyena accumulations, there were typically fewer of these bones, never exceeding $11 \%$ in the case of striped hyena (see also Cruz-Uribe 1991) (Fig. 12). Therefore, assemblages accumulated by spotted hyena on the one hand, and striped and brown hyena on the other, may be distinguished by the frequency of small compact bones. However, and as noted by Pokines and Kerbis-Peterhans (2007), the survivorship of small compact bones is likely to be positively influenced by prey size. A good example of this at Umm Jirsan is the high survivorship of equid astragali, and similar observations have been made in modern (Pokines and Kerbis-Peterhans 2007) and prehistoric hyena dens (Sala et al. 2020). 
Fig. 13 A Relative abundance of small hard bones (carpals, tarsals, phalanges) in the postcranial assemblage for spotted $(n=5)$, brown $(n=14)$, and striped $(n=5)$ hyena accumulations. B The relative abundance of carnivores in spotted $(n=13)$, brown $(\mathrm{n}=14)$, and striped $(n=7)$ hyena accumulations. Umm Jirsan data included. Modern comparative data from Cruz-Uribe (1991) and Kuhn et al. (2010)
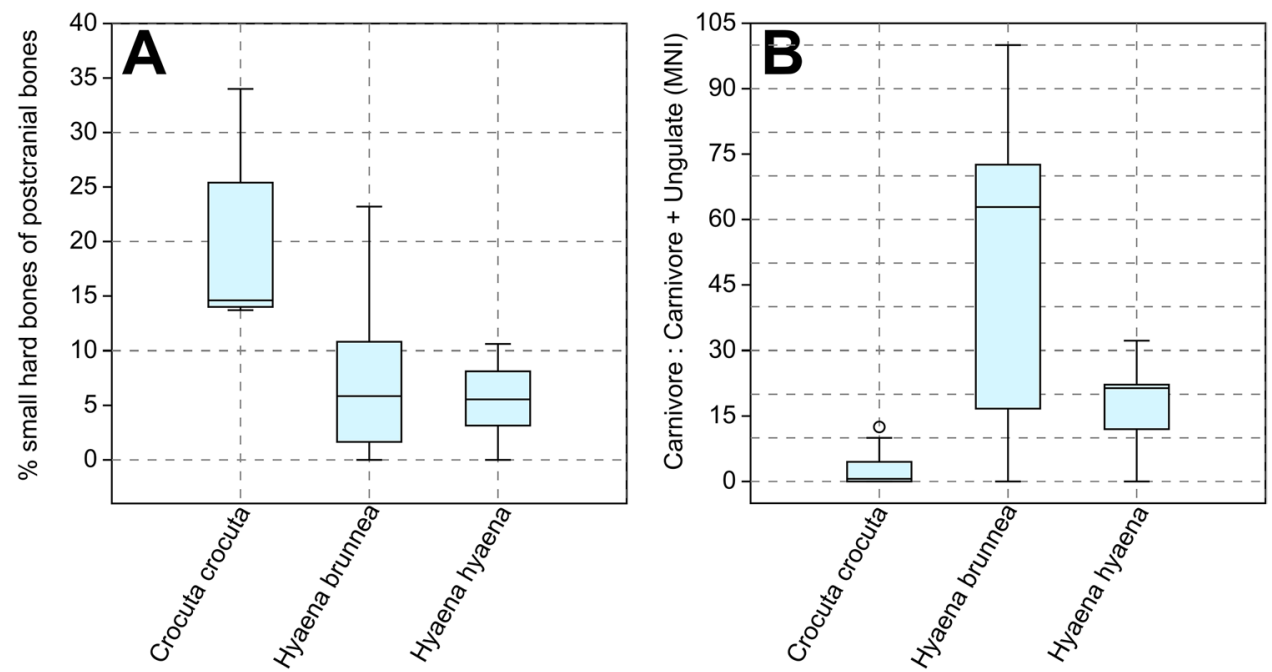

Our findings also capture the variation in striped hyena bone-accumulating and -modifying behavior. Firstly, we identify for the first time from a striped hyena den nondigestive corrosion of bone. Urine and feces, combined with high humidity and protection from subaerial environments, can produce conditions analogous to biologically active soil that promote the corrosion of bone, as has been observed in the dens of spotted hyena (Fernández-Jalvo and Andrews 2016). And secondly, we found gastric etching to be far more common at Umm Jirsan than has been reported from other striped hyena dens. Kuhn et al. (2010) found only a single gastrically etched bone in their analysis of nearly 1000 specimens from across five dens, while Fourvel et al. (2015) found none in their study of around 400 bones; although, this might be the result of recovery bias as sieving was not permitted for some of these sites. By comparison, 44 bones ( $4.8 \%$ of NISP) exhibit gastric etching at Umm Jirsan. The extent to which bones are digested may depend on the state of hunger of the animal (Fernández-Jalvo and Andrews 2016). To prolong digestion, famished animals retain food in their stomachs longer and may, as a result, more completely digest their stomach contents (Fernández-Jalvo and Andrews 2016). Therefore, it is possible that the differences in gastrically etched bone reflect differences in food availabilityi.e., the incomplete digestion of bone at Umm Jirsan might mean that resources were not limited, and this is consistent with the incomplete processing of equid lower limb elements at the site.

\section{Implications for prehistory and paleoecology}

The excellent preservation, abundance, and age of the material highlight the potential for future studies at Umm Jirsan and similar sites across the region. Very little remains known about the paleoecology and prehistory of northern Arabia, and this is, in no small part, due to the exceptionally scant fossil record. For instance, fossil evidence consistent with pastoralism in northern Arabia is restricted to just a few sites comprising very limited and/or fragmentary remains (Guagnin et al. 2017 2021; Scerri et al. 2018; Groucutt et al. 2020; Munoz et al. 2020; Thomas et al. 2021). In light of this, researchers have turned to the rock art record, the results of which have been illuminating (e.g., Guagnin et al. 2015 2018 2020). To give just one example, Guagnin et al. (2018) recently provided the first evidence that the distributions of African wild ass, aurochs, and lesser kudu extended into northern Arabia during the early- to mid-Holocene despite these animals being absent from the fossil record at that time. The Harrat Khaybar lava tubes, with their massive and exceptionally preserved carnivore accumulations, represent an untapped resource in an area where bone and fossil preservation are poor.

Indeed, other recent studies have demonstrated the potential of carnivore dens for the study of prehistory and paleoecology, particularly in arid regions where suitable archives are often scarce. By studying carnivore dens in the Judean Desert, Lazagabaster et al. (2021) showed that a shift in large carnivore community structure-namely the replacement of Arabian leopards with striped hyena as the dominate large carnivore in the landscape-coincided with an increase in human presence in the region, which they attribute to the active hunting of leopards and an increase in livestock scavenging opportunities for striped hyena. While authors of another recent study of striped hyena coprolites from central Iran argued that the "pollen encapsulated in these coprolites can be a major source of information on their environments, their foraging behavior and diet, as well as their interactions with human societies in the far and recent past" (Djamali et al. 2020 p. 17). The application of additional biomolecular approaches-DNA, stable isotope analysis, zooarchaeology by mass spectrometry, to name a few-should only further increase the potential of these sites for investigating the past. 


\section{Conclusion}

Carnivore neo-taphonomic studies in arid regions have been limited in number as well as in taphonomic detail. Here, we conducted a detailed taphonomic analysis of an impressive bone assemblage from a striped hyena den in the Harrat Khaybar lava field, northern Saudi Arabia. The material dates back as far as 7000 years, highlighting the exceptional preservation within the lava tube, and the potential for future research at Umm Jirsan and other nearby lava tubes. We identify here two potentially useful criteria for distinguishing between accumulations made by striped, spotted, and brown hyena. First is the ratio of carnivores to ungulates, and second is the percentage of small compact bones. In addition, the Umm Jirsan assemblage comprises more corroded bone-both gastrically and non-gastrically corroded - than has been reported in other studies of striped hyena bone accumulations. These findings highlight the need for continued neo-taphonomic studies for capturing the full variation of carnivore bone-accumulating and modifying behavior. Lastly, we show that the Harrat Khaybar lava tubes represent an untapped resource in a region where bone and fossil preservation is otherwise exceptionally poor. Such sites have the potential to inform on the paleoecology and prehistory of this understudied region. Although focusing primarily on striped hyena taphonomy, the present study hints that donkeys have been an important livestock in the region for thousands of years.

Supplementary Information The online version contains supplementary material available at https://doi.org/10.1007/s12520-021-01365-6.

Acknowledgements We thank the Saudi Ministry of Culture for permission to carry out fieldwork. We would like to thank, in particular, His Excellency Jasir Al-Herbish and Dr. Abdullah Al Zahrani of the Saudi Heritage Commission for support of this project. MS thanks Emmanuel Gilissen of the Royal Museum for Central Africa in Tervuren, Belgium, for providing access to comparative material. Great appreciations to the Saudi Geological Survey president Eng. Houssain Otaibi, vice-president Mr. Saleh Sefry, and director of the Geological Survey Program Dr. Wadee Kashghari for their tremendous logistic support. We also thank geologists Saleh A. Alsoubhi, Mohammed Haptari, and Hisham Hashim for their assistance in the field.

Funding Open Access funding enabled and organized by Projekt DEAL. Financial support for our research has been provided by the Max Planck Society, the Leverhulme Trust (RPG-2017-087), and the Saudi Heritage Commission. SJA's contribution to this work was partly supported by the Research Council of Norway, through its Centers of Excellence funding scheme, SFF Centre for Early Sapiens Behaviour (SapienCE), project number 262618. AMA acknowledges the support from the Researchers Supporting Project of King Saud University no. RSP-2019/126.

Data availability All data is available from the corresponding author on request.

\section{Declarations}

Conflict of interest The authors declare no competing interests.

Open Access This article is licensed under a Creative Commons Attribution 4.0 International License, which permits use, sharing, adaptation, distribution and reproduction in any medium or format, as long as you give appropriate credit to the original author(s) and the source, provide a link to the Creative Commons licence, and indicate if changes were made. The images or other third party material in this article are included in the article's Creative Commons licence, unless indicated otherwise in a credit line to the material. If material is not included in the article's Creative Commons licence and your intended use is not permitted by statutory regulation or exceeds the permitted use, you will need to obtain permission directly from the copyright holder. To view a copy of this licence, visit http://creativecommons.org/licenses/by/4.0/.

\section{References}

Alados CJ, Escós J (1991) Phenotypic and genetic characteristics affecting lifetime reproductive success in female Cuvier's dama and dorcas gazelles (Gazella cuvieri, G. dama and G. dorcas). J Zool 223:307-321

Andrés M, Gidna AO, Yravedra J, Domínguez-Rodrigo M (2012) A study of dimensional differences of tooth marks (pits and scores) on bones modified by small and large carnivores. Archaeol Anthropol Sci 4:209-219

Andrews P (2008) Cetaceans from a possible striped hyaena den site in Qatar. J Taphon 6:255-274

Arilla M, Rosell J, Blasco R (2018) Contributing to characterise wild predator behaviour: consumption pattern, spatial distribution and bone damage on ungulate carcasses consumed by red fox (Vulpes vulpes). Archaeol Anthropol Sci 11:2271-2291

Arriaza MC, Domínguez-Rodrigo M, Yravedra J, Baquedano E (2016) Lions as bone accumulators? Paleontological and ecological implications of a modern bone assemblage from Olduvai Gorge. PLoS ONE 11(5):e0153797

Arsuaga JL, Baquendano E, Pérez-González A, Sala N, Quam RM, Rodríguez L, García R, García N, Álvarez-Lao DJ, Laplana C, Huguet R, Sevilla P, Maldonado E, Blain H-A, Ruiz-Zapata B, Sala P, Gil-García J, Uzquiano P, Pantoja A, Márquez B (2012) Understanding the ancient habitats of the last-interglacial (late MIS 5) Neanderthals of central Iberia: paleoenvironmental and taphonomic evidence from the Cueva del Camino (Spain) site. Quatern Int 275:55-75

Bärmann EV, Börner S, Erpenbeck D, Rössner GE, Hebel C, Wörheide G (2013) The curious case of Gazella arabica. Mamm Biol 47:220-225

Behrensmeyer AK (1978) Taphonomic and ecological information from bone weathering. Paleobiology 4:150-162

Binford LR (1981) Bones: ancient men and modern myths. New York Academic Press, New York

Binford LR (1984) Faunal remains from Klasies River Mouth. Academic Press, Orlando

Blumenschine RJ (1986) Carcass consumption sequences and the archaeological distinction of scavenging and hunting. J Hum Evol 15:639-659

Blumenschine RJ (1988) An experimental model of the timing of hominin and carnivore influence on archaeological bone assemblages. J Archaeol Sci 15:483-502 
Blumenschine RJ, Madrigal TC (1993) Variability in long bone marrow yields of East African ungulates and its zooarchaeological implications. J Archaeol Sci 20:555-587

Bothma JDP (1998) Carnivore ecology in arid lands. Springer-Verlag, New York

Brain CK (1980) Some criteria for the recognition of bone-collecting agencies in African Caves. In: Behrensmeyer AK, Hill AP (eds) Fossils in the making: vertebrate taphonomy and paleoecology. University of Chicago Press, Chicago, pp 107-130

Brain CK (1981) The hunters or the hunted? University of Chicago Press, Chicago, An introduction to African cave Taphonomy

Buckland-Wright JC (1969) Craniological observations on Hyaena and Crocuta (Mammalia). J Zool 159:17-29

Bunn, H.T., 1982. Meat-eating and human evolution: studies on the diet and subsistence patterns of Plio-Pleistocene Hominids in East Africa. Ph.D. dissertation, University of Wisconsin, Madison.

Bunn HT, Pickering TR (2010) Bovid mortality profiles in paleoecological context falsify hypotheses of endurance running-hunting and passive scavenging by early Pleistocene hominins. Quatern Res 74:395-404

Capaldo SD (1997) Experimental determination of carcass processing by Plio-Pleistocene hominids and carnivores at FLK 22 (Zinjanthropus), Olduvai Gorge, Tanzania. J Hum Evol 33:555-597

Cattani M, Bökönyi S (2002) Ash-Shumah: an early Holocene settlement of desert hunters and mangrove foragers in the Yemeni Tihamah. In: Cleuziou S, Tosi M, Zarins J (eds) Essays on the Late Prehistory of the Arabian Peninsula. Instituto Italiano per l'Africa e l'Oriente, Rome, pp 31-55

Chuang R, Bonhomme V (2019) Rethinking the dental morphological differences between domestic equids. J Archaeol Sci 101:140-148

Courtenay LA, Yravedra J, Huguet R, Ollé A, Aramedni J, MatéGonzález MA, González-Aguilera D (2019) New taphonomic advances in 3D digital microscopy: a morphological characterisation of trampling marks. Quatern Int 517:55-66

Cruz-Uribe K (1991) Distinguishing hyena from hominid bone accumulations. J Field Archaeol 18:467-486

Delagnes A, Tribolo C, Bertran P, Brenet M, Crassard R, Jaubert J, Khalidi L, Mercier N, Nomade S, Peigné S, Sitzia L, Tournepiche JF, Al-Halibi M, Al-Mosabi A, MacChiarelli R (2012) Inland human settlement in southern Arabia 55,000 years ago. New evidence from the Wadi Surdud Middle Paleolithic site complex, western Yemen. J Hum Evol 63:452-474

Djamali M, Mashkour M, Akhani H, Belkacem D, Gambin B, Leydet M, Samadi N, Tengberg M, Gandouin M (2020) Pollen analysis of present-day striped hyena (Hyaena hyaena) scats from central Iran: implications for dryland paleoecology and animal paleoethology. Rev Palaeobot Palynol 281:104277

Dobney K, Rielly K (1988) A method for recording archaeological animal bones: the use of diagnostic zones. Circaea 5:79-96

Domínguez-Rodrigo M (1999) Flesh availability and bone modifications in carcasses consumed by lions: palaeoecological relevance in hominid foraging patterns. Palaeogeogr Palaeoclimatol Palaeoecol 149:373-388

Domínguez-Rodrigo M (2001) A study of carnivore competition in riparian and open habitats of modern savannas and its implication for hominid behavioral modelling. J Hum Evol 40:77-98

Domínguez-Rodrigo M (2019) Successful classification of experimental surface modifications (BSM) through machine learning algorithms: a solution to the controvesial use of BSM in paleoanthropology? Archaeol Anthropol Sci 11:2711-2725

Domínguez-Rodrigo M, Egeland CP, Barba R (2007) Deconstructing Olduvai: a taphonomic study of the bed I sites. Springer, New York
Domínguez-Rodrigo M, Gidna AO, Yravedra J, Musiba C (2012) A comparative neo-taphonomic study of felids, hyaenids, and canids: an analogical framework based on long bone modification patterns. J Taphon 10:151-170

Domínguez-Rodrigo M, Pickering TR (2010) A multivariate approach for discriminating bone accumulations created by spotted hyenas and leopards: harnessing actualistic data from East and southern Africa. J Taphon 8:155-179

Domínguez-Rodrigo M, Yravedra J (2009) Why are cut mark frequencies in archaeofaunal assemblages so variable? A multivariate analysis. J Arhcaeol Sci 36:884-894

Drechsler P (2007) The Neolithic dispersal into Arabia. Proceedings of the Seminar for Arabian Studies 37:93-109

Eisenmann V, Beckouche S (1986) Identification and discrimination of metapodials from Pleistocene and modern Equus, wild and domestic. Beihefte zum Tübinger Atlas des Vorderen Orients Reihe A, Naturwissenschaften 19:117

Faith JT, Behrensmeyer AK (2006) Changing patterns of carnivore modification in a landscape bone assemblage, Amboseli Park, Kenya. J Archaeol Sci 33:1718-1733

Faith JT, Gordon AD (2007) Skeletal element abundances in archaeofaunal assemblages: economic utility, sample size, and assessment of carcass transport strategies. J Archaeol Sci 34:872-882

Fernández-Jalvo Y, Andrews P (2016) Atlas of taphonomic identifications. Springer, Dordrecht

Fosse P, Selva N, Smietana W, Okarma H, Wajrak A, Fourvel JB, Madelaine S, Esteban-Nadal M, Cáceres I, Yravedra J, Brugal JP, Prucca A, Haynes G (2012) Bone modification of modern wolf (Canis lupus): a taphonomic study from their natural feeding places. J Taphon 10:197-217

Fourvel J-B, Fosse P, Avery G (2015) Spotted, striped or brown? Taphonomic studies at dens of extant hyaenas in eastern and southern Africa. Quatern Int 369:38-50

Gidna A, Domínguez-Rodrigo M, Pickering TR (2015) Patterns of bovid long limb bone modification created by wild and captive leopards and their relevance to the elaboration of referential frameworks for paleoanthropology. J Archaeol Sci Rep 2:302-309

Gidna A, Yravedra J, Domínguez-Rodrigo M (2013) A cautionary note on the use of captive carnivores to model wild predator behavior: a comparison of modification patterns on long bones by captive and wild lions. J Archaeol Sci 40:1903-1910

Groucutt HS (2020) Volcanism and human prehistory in Arabia. J Volcanol Geotherm Res 402:107003

Groucutt H, Breeze PS, Guagnin M, Stewart M, Drake N, Shipton C, Zahrani B, al Omari A, Alsharekh A, Petraglia MD (2020) Monumental landscapes of the Holocene humid period in northern Arabia: the mustatil phenomenon. Holocene 30:1767-1779

Groucutt HS, Grün R, Zalmout IAS, Drake NA, Armitage SJ, Candy I, Clark-Wilson R, Louys J, Breeze PS, Duval M, Buck LT, Kivell TL, Pomeroy E, Stephens NB, Stock JT, Stewart M, Price GJ, Kinsley L, Sung WW, Alsharekh A, Al-Omari A, Zahir M, Memesh AM, Abdulshakoor AJ, Al-Masari AM, Bahameem AA, Al Murayyi KMS, Zahrani B, Scerri ELM, Petraglia MD (2018) Homo sapiens in Arabia by 85,000 years ago. Nat Ecol Evol 2:1-10

Groucutt HS, Petraglia MD (2012) The prehistory of the Arabian Peninsula: deserts, dispersals, and demography. Evol Anthropol 21:113-125

Groves CP, Lay DM (1985) A new species of the genus Gazella (Mammalia: Artiodactyla: Bovidae) from the Arabian Peninsula. Mammalia 49:27-36

Guagnin M, Breeze P, Shipton C, Ott F, Stewart M, Bateman M, Martin L, Graham L, el-Dossary S, Kingwell-Banham E, Badr Z, al-Omari A, Alsharekh AM, Petraglia M (2020) The Holocene humid period in the Nefud Desert: hunters and herders in 
the Jebel Oraf palaeolake basin, Saudi Arabia. J Arid Environ 178:104146

Guagnin M, Jennings R, Clark-Balzan L, Groucutt HS, Parton A, Petraglia MD (2015) Hunters and herders: exploring the Neolithic transition in the rock art of Shuwaymis, Saudi Arabia. Archaeol Res Asia 4:3-16

Guagnin M, Shipton C, el-Dossary S, al-Rashid M, Moussa F, Stewart M, Ott F, Alsharekh A, Petraglia MD (2018) Rock art provides new evidence on the biogeography of kudu (Tragelaphus imberbis), wild dromedary, aurochs (Bos primigenius) and African wild ass (Equus africanus) in the early and middle Holocene of north-western Arabia. J Biogeogr 45:727-740

Guagnin M, Shipton C, Martin L, Kingwell-Banham E, Breeze P, Graham L, Ott F, Stewart M, El-Dossary S, Zahrani B, Al-Omari A, Alsharekh A, Petraglia MD (2021) A tale of two hearth sites: Neolithic and intermittent mid to late Holocene occupations in the Jubbah oasis, northern Saudi Arabia. Archaeol Res Asia 26: 100278

Guagnin M, Shipton C, Martin L, Petraglia M (2017) The Neolithic site of Jebel Oraf 2, northern Saudi Arabia: first report of a directly dated site within faunal remains. Archaeol Res Asia 9:63-67

Hammer Ø, Harper DAT, Ryan PD (2001) PAST: palaeontological statistics software package for education and data analysis. Palaeontologica Electronica 4:1-9

Harris JA, Marean CW, Ogle K, Thompson J (2017) The trajectory of bone surface modification studies in paleoanthropology and a new Bayesian solution to the identification controversy. J Hum Evol 110:69-81

Harrison, D.L., Bates, P.J.J., 1991. The mammals of Arabia. Harrison Zoological Museum, Sevenoaks.

Helmer D, Gourichon L, Monchot H, Peters J, Segui MS (2005) Identifying early domestic cattle from Pre-Pottery Neolithic sites on the Middle Euphrates using sexual dimorphism. In: Vigne J-D, Peters J, Helmer D (eds) First Steps of Animal Domestication. Oxbow Books, UK, pp 86-95

Hofer, H., 1998. Striped Hyaena Hyaena (Hyaena) hyaena (Linnaeus, 1758). Pp. 21-26 in Mills, M.G.L. and Hofer, H. eds. Hyaenas: status survey and conservation action plan. IUCN/SSC Hyaena Specialist Group. IUCN, Gland, Switzerland and Cambridge, UK.

Horwitz LK, Smtih P (1988) The effects of striped hyaena activity on human remains. J Archaeol Sci 15:471-481

Jones KE, Bielby J, Cardillo M, Fritz SA, O’Dell J, Orme CDL, Safi K, Sechrest W, Boakes EH, Carbone C, Connolly C, Cutts MJ, Foster JK, Grenyer R, Habib M, Plaster CA, Price SA, Rigby EA, Rist J, Teacher A, Bininda-Emonds ORP, Gittleman JL, Mace GM, Purvis A (2009) PanTHERIA: a species-level database of life history, ecology, and geography of extant and recently extinct mammals. Ecology 90:2648

Kempe S, Al-Malabeh A, Döppes D, Frehat M, Henschel H-V, Rosendahl W (2006) Hyena caves in Jordan. Scientific Annals, School of Geology Aristotle University of Thessaloniki 98:201-212

Kerbis-Peterhans JC, Horwitz LK (1992) A bone assemblage from a striped hyena (Hyaena hyaena) den in the Negev Desert, Israel. Isr J Zool 37:225-245

Krajcarz M, Krajcarz MT (2014) The red fox (Vulpes vulpes) as an accumulator of bones in cave-like environments. Int J Osteoarchaeol 24:459-475

Kruuk H (1976) Feeding and social behavior of the striped hyaena (Hyaena vulgari Desmarest). East Afr Wildl J 14:91-111

Kuhn BF (2005) The faunal assemblages and taphonomic signatures of five striped hyaena (Hyaena hyaena syriaca) dens in the desert of eastern Jordan. Levant 37:221-234

Kuhn BF, Berger LR, Skinner JD (2010) Examining criteria for identifying and differentiating fossil faunal assemblages accumulated by hyenas and hominins using extant hyenid accumulations. Int J Osteoarchaeol 20:15-35

Kürschner H (1998) Biogeography and introduction to vegetation. In: Ghazanfar SA, Fisher M (eds) Vegetation of the Arabian Peninsula. Springer, Dordrecht, pp 63-98

Lam YM, Chen X, Pearson OM (1999) Intertaxonomic variability in patterns of bone density and the differential representation of bovid, cervid and equid elements in the archaeological record. Am Antiq 64:343-362

Lansing SW, Cooper SM, Boydston EE, Holekamp KE (2009) Taphonomic and zooarchaeological implications of spotted (Crocuta crocuta) bone accumulations in Kenya: a modern behavioral ecological approach. Paleobiology 35:289-309

Laurenson MK (1993) Early maternal behavior of wild cheetahs: implications for captive husbandry. Zoo Biol 12:31-43

Lazagabaster IA, Ullman M, Porat R, Halevi R, Porat N, Davidovich U, Marom N (2021) Changes in the large carnivore community structure of the Judean Desert in connection to Holocene settlement dynamics. Sci Rep 11:3548

Leakey LN, Milledge SAH, Leakey SM, Edung J, Haynes P, Kiptoo DK, McGeorge A (1999) Diet of striped hyaena in northern Kenya. Afr J Ecol 37:314-326

Levine, M.A., 1982. The use of crown height measurements and eruption-wear sequences to age horse teeth. Pp. 223-250 in Wilson, B., Grigson, C. and Payne, S. eds. Ageing and sexing animals bones from archaeological sites. BAR British Series 109, Oxford

Louys J, Meloro C, Elton S, Ditchfield P, Bishop LC (2015) The potential and pitfalls of using simple dental metrics to infer the diets of African antelopes (Mammalia: Bovidae). Palaeontol Afr 49:8-24

Lyman RL (2018) Actualistic neotaphonomic research on bone modifying animal species: an analysis of the literature. Palaios 33:542-554

Macdonald DW (1978) Observations on the behavior and ecology of the striped hyaena, Hyaena hyaena, in Israel. Isr J Zool 27:189-198

Maguire JM, Pemberton D, Collett MH (1980) The Makapansgat limeworks grey breccia: Hominids, hyenas, hystricids or hillwash? Palaeontologica Africana 23:75-98

Makarewicz CA (2020) The adoption of cattle pastoralism in the Arabian Peninsula: a reappraisal. Arab Archaeol Epigr 31:168-177

Marean CW, Spencer LM (1991) Impact of carnivore ravaging of bone in archaeological assemblages. J Archaeol Sci 18:667-694

Marean CW, Spencer LM, Blumenschine RJ, Capaldo SD (1992) Captive hyaena bone choice and destruction, the Schlepp effect and Olduvai archaeofaunas. J Archaeol Sci 19:101-121

Marshall F (2007) African pastoral perspectives on domestication of the donkey: a first syntehsis. In: Denham T, Iriarte J, Vrydaghs L (eds) Rethinking agriculture: archaeological and ethnoarchaeological perspectives. Left Coast Press, Routledge, London, pp 371-407

Marshall F, Weissbrod L (2011) Domestication process and morphological change: through the lense of donkey and African pastoralism. Curr Anthropol 52:328-413

Martin L, McCorriston J, Crassard R (2009) Early Arabian pastoralism at Manayzah in Wādī Sanā Hadramawt. Proceedings of the Seminar for Arabian Studies 39:271-282

Mech, L.D., 1974. Canis lupus. Mammalian Species 37:1-6

Metcalfe D, Jones KT (1988) A reconsideration of animal body-part utility indices. Am Antiq 53:486-504

Milevski I, Horwitz LK (2019) Domestication of the Donkey (Equus asinus) in the southern Levant: archaeozoology, iconography and economy. In: Kowner R, Bar-Oz G, Biran M, Shahar M, Shelach-Lavi G (eds) Animals and human society in Asia: historical, cultural and ethical perspectives. Palgrave Macmillan, Cham, pp 93-148 
Moclán A, Huguet R, Márquez B, Laplana C, Arsuaga JL, PérezGonzález A, Baquedano E (2020) Identifying the bone-breaker at the Navalmaíllo Rock Sheleter (Pinilla del Valle, Madrid) using machine learning algorithms. Archaeol Anthropol Sci 12:46

Monchot H, Mashkour M (2010) Hyenas around the city (Kashan, Iran). J Taphon 8:17-32

Munoz O, Cotty M, Charloux G, Bouchaud C, Monchot H, Marquaire C, Zazzo A, Crassard R, Brunet O, Boschloos V, al-Malki T (2020) Marking the sacral landscape of a north Arabian oasis: a sixth-millennium BC monumental stone platform surrounding burials. Antiquity 94:601-621

Munro ND, Bar-Oz G, Stutz AJ (2009) Aging mountain gazelle (Gazella gazelle): refining methods of tooth eruption and wear and bone fusion. J Archaeol Sci 36:752-763

Packer C, Pusey AE (1997) Divided we fall: cooperation among lions. Sci Am 276:52-59

Pante MC, Blumenschine RJ, Capaldo SD, Scott RS (2012) Validation of bone surface modification models for inferring fossil hominin and carnivore feeding interactions, with reapplications to FLK 22, Olduvai Gorge, Tanzania. J Hum Evol 63:395-407

Pante MC, Muttart MV, Keevil TL, Blumenschine RJ, Njau JK, Merritt SR (2017) A new high-resolution 3-D quantitative method for identifying bone surface modifications with implications for the Early Stone Age archaeological record. J Hum Evol 102:1-11

Payne S (1973) Kill-off patterns in sheep and goats: the mandibles from Asvan Kale. Anatol Stud 23:281-303

Petraglia MD, Groucutt HS, Parton A, Alsharekh A (2015) Green Arabia: Human prehistory at the cross-roads of continents. Quat Int 382:1-7

Petraglia MD, Groucutt HS, Guagnin M, Breeze PS, Boivin N (2020) Human responses to climate and ecosystem change in ancient Arabia. PNAS 117:8263-8270

Pickering TR (2002) Reconsideration of criteria for differentiating faunal assemblages accumulated by hyenas and hominids. Int $\mathbf{J}$ Osteoarchaeol 12:127-141

Pint, J., 2009. Umm Jirsan: Arabia's longest lava-tube system. Paper presented at the $15^{\text {th }}$ International Congress of Speleology.

Pobiner, B. L., 2007. Hominin-carnivore interactions: evidence from modern carnivore bone modification and Early Pleistocene archaeofaunas (Koobi Fora, Kenya; Olduvai Gorge, Tanzania). Ph.D. dissertation, Rutgers University, New Jersey, USA.

Pokines JT, Kerbis-Peterhans JC (2007) Spotted hyena (Crocuta crocuta) den use and taphonomy in the Masai Mara National Reserve, Kenya. J Archaeol Sci 34:1914-1913

Reimer PJ, Austin WEN, Bard E, Bayliss A, Blackwell PG, Ramsey CB, Butzin M, Cheng H, Edwards RL, Friedrich M, Grootes PM, Guilderson TP, Hajdas I, Heaton TJ, Hogg AG, Hughen KA, Kromer B, Manning SW, Muscheler R, Palmer JG, Pearson C, van der Plicht J, Reimer RW, Richards DA, Scott EM, Southon JR, Turney CSM, Wacker L, Adolphi F, Büntgen U, Capano M, Fahrni SM, Fogtmann-Schulz A, Friedrich R, Köhler P, Kudsk S, Miyake F, Olsen J, Reinig F, Sakamoto M, Sookdeo A, Talamo S (2020) The IntCal20 Northern Hemisphere radiocarbon age calibration curve (0-55 cal kBP). Radiocarbon 46:725-757

Rieger I (1979) A review of the biology of the striped hyaenas, Hyaena hyaena (Linné, 1758). Säugetierkundliche Mitteilungen 27:81-95

Roobol, M.J., Camp, V.E., 1991. Geologic map of the Cenozoic lava field of Harrats Khaybar, Ithnayn, and Kure, Kingdom of Saudi Arabia. Saudi Directorate General of Mineral Resources Geoscience Map GM-131, with explanatory text, p. 60.

RStudio Team, 2015. RStudio: integrated development for R. RStudio, Inc., Boston, MA. http://www.rstudio.com.
Sala N, Arsuaga JL (2018) Regarding beasts and humans: a review of taphonomic works with living carnivores. Quatern Int 466:131-140

Sanz M, Daura J, Égüez N, Brugal J-P (2016) Not only hyenids: a multi scale analysis of Upper Pleistocene carnivore coprolites in Cova del Coll Verdaguer (NE Iberian Peninsula). Palaeogeogr Palaeoclimatol Palaeoecol 443:249-262

Sala N, Arsuaga JL, Haynes G (2014) Taphonomic comparison of bone modifications caused by wild and captive wolves (Canis lupus). Quatern Int 330:126-135

Sala N, Pablos A, Gómez-Olivencia A, Sanz A, Villalba M, PantojaPérez A, Laplana C, Arsuaga JL, Algaba M (2020) Central Iberia in the middle MIS 3 Paleoecological inferences during the period 34-40 cal kyr BP. Quatern Sci Rev 228:106027

Scerri EML, Guagnin M, Groucutt HS, Armitage SJ, Parker LE, Drake N, Louys J, Breeze PS, Zahir M, Alsharekh A, Petraglia MD (2018) Neolithic pastoralism in marginal environments during the Holocene Humid Period, northern Saudi Arabia. Antiquity 92:1180-1194

Schick, K., Toth, N., Gehling, T., Pickering, T.R., 2007. Taphonomic analysis of an excavated striped hyena den from the Eastern Desert of Jordan. Pp. 75-106 in Pickering, T.R., Schick, K. and Toth, N. eds. Breathing life into fossils: taphonomic studies in honor of C.K. (Bob) Brain. Stone Age Institute Press, Gosport, Indiana.

Selvaggio MM (1994) Carnivore tooth marks and stone tool butchery marks on scavenged bones: archaeological implications. J Hum Evol 27:215-228

Singh P, Gopalaswamy AM, Karanth KU (2010) Factors influencing densities of striped hyenas (Hyaena hyaena) in arid regions of India. J Mammal 91:1152-1159

Skinner JD, Davis S, Ilani G (1980) Bone collecting by striped hyaenas, Hyaena hyaena, in Israel. Palaeontologica Africana 23:99-104

Skinner JD, Ilani G (1979) The striped hyaena Hyaena hyaena of the Judean and Negev Deserts and a comparison with the brown hyaena $H$. brunnea. Isr J Zool 28:229-232

Stewart M, Clark-Wilson RC, Breeze PS, Janulis K, Candy I, Armitage SJ, Ryves DB, Louys J, Duval M, Price GJ, Cuthbertson P, Bernal MA, Drake NA, Alsharekh AM, Zahrani B, al Omari A, Roberts P, Groucutt HS, Petraglia MD (2020) Human footprints provide snapshot of last interglacial ecology in the Arabia interior. Sci Adv 6:eaba8940

Stewart M, Louys J, Groucutt HS, Candy I, Clark-Wilson R, Breeze PS, Drake NA, Price GJ, Al-Mufarreh YSA, Soubhi SA, Zalmout IS, Alsharekh AM, al Omari A, Petraglia MD (2019) Taphonomic and zooarchaeological investigations at the middle Pleistocene site of Ti's al Ghadah, western Nefud Desert, Saudi Arabia. Quat Sci Rev 218:228-253.

Stiner MC (1990) The use of mortality patterns in archaeological studies of hominid predatory adaptations. J Anthropol Archaeol 9:305-351

Thomas H, Kennedy M, McMahon J, Strolin L, Franklin D, Flavel A, Noble J, Swift L (2021) Monumentality, social memory, and territoriality in Neolithic-Chalcolithic northwestern Arabia. J Field Archaeol. https://doi.org/10.1080/00934690.2021. 1892323

Uerpmann, H.-P., 1987. The Ancient distribution of ungulate mammals in the Middle East. Beihefte zum Tübinger Atlas des Vorderen Orients. Wiesbaden: Dr Ludwig Reichert.

Uerpmann H-P (1991) Equus africanus in Arabia. In: Meadow RH, Uerpmann H-P (eds) Equids in the Ancient World, vol 2. Ludwig Reichert Verlag, Wiesbaden, pp 12-33

Uerpmann H-P, Uerpmann H-P (2012) Archaeozoology of camels in south-eastern Arabia. In: Knoll R, Burger P (eds) Camels in Asia 
and North Africa: interdisciplinary perspectives on their past and present significance. Academy of Sciences Press, Vienna, pp 109-122

Villa P, Mahieu E (1991) Breakage pattern of human long bones. J Hum Evol 21:27-48

von den Driesch A (1976) A guide to the measurement of animal bones from archaeological sites. Peabody Museum Press, Harvard University

Wagner, A.P., 2006. Behavioral ecology of the striped hyena (Hyaena hyaena). Ph.D. Dissertation, Montana State University, Bozeman, Montana.

Yravedra J, Fosse P, Besson JP (2014) Taphonomic analysis of small ungulates modified by fox (Vulpes vulpes) in southwestern Europe. Journal of Taphonomy 12:37-67

Yravedra J, Lagos L, Bárcena F (2011) A taphonomic study of wild wolf (Canis lupus) modification of horse bones in northwestern Spain. J Taphon 9:37-65
Yravedra J, Lagos L, Bárcena F (2012) The wild wolf (Canis lupus) as a dispersal agent of animal carcasses in northwestern Spain. J Taphon 10:227-248

Zeder MA (2006) Reconciling rates of long bone fusion and tooth eruption and wear in sheep (Ovis) and goat (Capra). In: Ruscillo D (ed) Recent advances in ageing and sexing animal bones. Oxbow book, Oxford, pp 87-118

Zeder MA (2017) Out of the Fertile Crescent: the dispersal of domestic livestock through Europe and Africa. In: Boivin N, Crassard R, Petraglia M (eds) Human dispersal and species movement. Cambridge University Press, Cambridge, pp 261-303

Zeder MA, Hesse B (2000) The initial domestication of goats (Capra hircus) in the Zagros Mountains 10,000 years ago. Science 24:2254-2257

Publisher's note Springer Nature remains neutral with regard to jurisdictional claims in published maps and institutional affiliations. 